\title{
A Geologic and Mineral Exploration Spatial Database for the Stillwater Complex, Montana
}

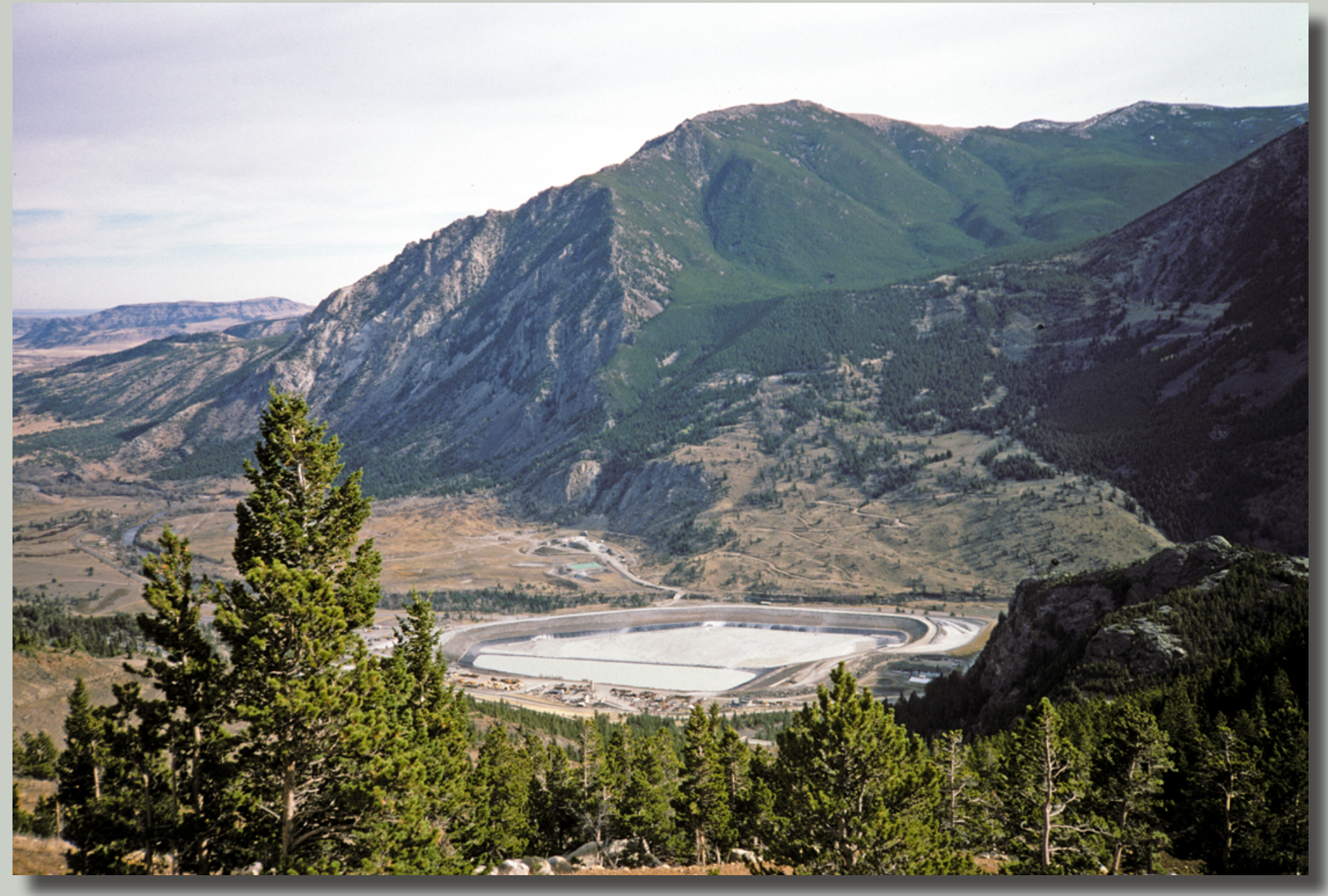

Scientific Investigations Report 2014-5183 
Cover photograph: The east side of the Stillwater River canyon, near Nye, Montana. The prominent outcrops in the canyon wall are plagioclase-rich, layered igneous rocks of the Stillwater Complex. The tailing pond of the Stillwater Mine is in the foreground. The Stillwater Mine produces palladium and platinum from the J-M Reef, an igneous layer in the Stillwater Complex. Photograph by Michael L. Zientek. 


\section{A Geologic and Mineral Exploration Spatial Database for the Stillwater Complex, Montana}

By Michael L. Zientek and Heather L. Parks

Scientific Investigations Report 2014-5183

U.S. Department of the Interior

U.S. Geological Survey 


\section{U.S. Department of the Interior SALLY JEWELL, Secretary}

\section{U.S. Geological Survey Suzette Kimball, Acting Director}

\section{U.S. Geological Survey, Reston, Virginia: 2014}

For more information on the USGS - the Federal source for science about the Earth, its natural and living resources, natural hazards, and the environment—visit

http://www.usgs.gov or call 1-888-ASK-USGS

For an overview of USGS information products, including maps, imagery, and publications, visit http://www.usgs.gov/pubprod

To order this and other USGS information products, visit http://store.usgs.gov

Suggested citation:

Zientek, M.L., and Parks, H.L., 2014, A geologic and mineral exploration spatial database for the Stillwater Complex, Montana: U.S. Geological Survey Scientific Investigations Report 2014-5183, 28 p., http://dx.doi.org/10.3133/ sir20145183.

Any use of trade, product, or firm names is for descriptive purposes only and does not imply endorsement by the U.S. Government.

Although this report is in the public domain, permission must be secured from the individual copyright owners to reproduce any copyrighted material contained within this report.

ISSN 2328-0328 (online) 


\section{Acknowledgments}

Many people from different organizations have helped in the preparation of this compilation. From the USGS, we would like to acknowledge J. Douglas Causey, Pam Dunlap, Lorre

Moyer, Walt Bawiec, Pam Cossette, Bruce R. Lipin, Rozalind R. Helz, Brad van Gosen, Peter Portolos, Susan Garcia, and Niki Wintzer. Kenneth C. Assmus, Mary H. Carlson, Ellen Burch, Connie Causey, Tracy Grover, Helen Z. Kayser, Bill Kelly, all contractors working for the USGS in Spokane, made significant contributions. We would also like to acknowledge the work done by Mike Carver, Shyla Hatch, Mike Koenig, Michael Landkammer, J.C. Larsen, Tom Mooney, Rebecca A. Pitts, and Rick West at Eastern Washington University. Michel Coffey, with the Montana Bureau of Mines and Geology gave permission to use information previously published in MBMG Special Publication 92.

This compilation would not have been possible without the assistance and cooperation with exploration and mining companies. In particular, we would like to acknowledge the assistance of Bob Mann and Sam Corson with Johns-Manville-Manville-Stillwater PGM Resources; Alistair R. Turner with the Anaconda Company and Boulder Group N.L.; Dick Vian with Stillwater Mining Company; and Marvin Ratcliff and John Wilson with the Anaconda Company.

The authors are grateful for helpful and constructive technical reviews provided by USGS colleagues Connie Dicken and Pamela Cossette. 


\section{Contents}

Abstract

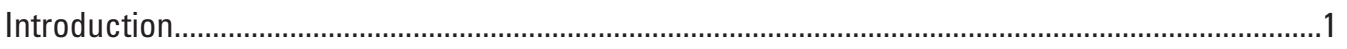

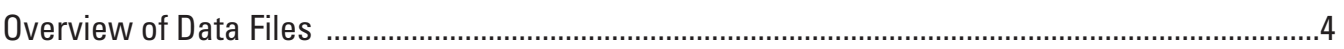

Stillwater Complex—Rock Types and Geologic Map Units.............................................................

Geologic Map of the Stillwater Complex, Montana (Page and Nokleberg, 1974)....................8

Geologic Map of the Banded Upper Zone of the Stillwater Complex and Adjacent Rocks (Segerstrom and Carlson, 1982) .................................................................................

Maps of the East Boulder Plateau (Montana Bureau of Mines and Geology Special

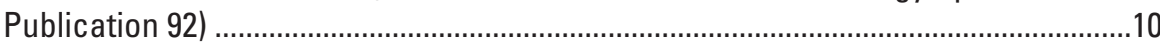

Mineral Resource Assessment of the Absaroka-Beartooth Study Area (Hammarstrom and

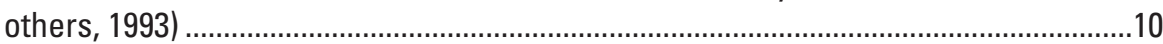

Description of Feature Classes in Stillwater_Complex.gdb_Geologic Maps...............................10

Feature Classes from Page and Nokleberg (1974) (I797_poly, 1797_line, 1797_point) ............10

Feature Classes from USGS Miscellaneous Investigation Series I-1383 (I1383_poly, I1383_

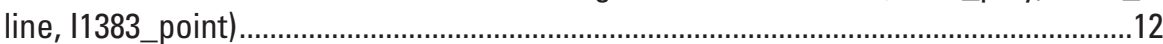

Feature Classes from USGS Open-File Report 93-207 (OF93_207_poly, OF93_207_line)........12

Feature Classes from Montana Bureau of Mines and Geology Special Publication 92 (SP92S3FP_poly, SP92S4EBP_poly, SP92S4EBP_line, SP92S4EBP_point) ................12

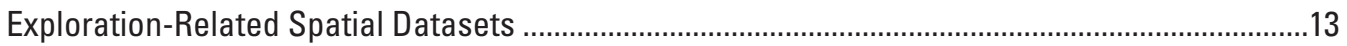

Nickel and Copper in Contact-Type Deposits …….........................................................15

Chromium — The G and H Chromite Seams ..................................................................16

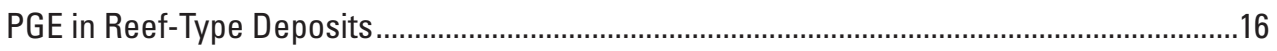

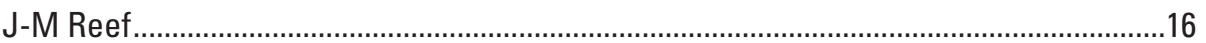

PGE-Enriched A and B Chromite Seams...................................................................18

PGE in Other Deposit Types.............................................................................................18

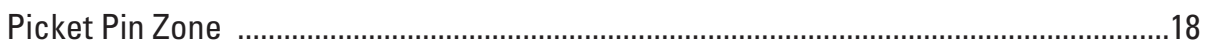

Pegmatoidal Lenses, Pipes, and Other Discordant Mineralization .................................19

Other Styles of Mineralization .....................................................................................19

Description of Feature Classes in Stillwater_Complex.gdb_Exploration Datasets.......................19

Mine Tunnels, Shafts, Adits, and Portals, Stillwater Complex, Montana (still_mines) ...........19

Copper and Nickel Soil Geochemistry, Stillwater Complex, Montana (amax_soil_gchm)....19

Platinum and Palladium Soil Samples, Stillwater Complex, Montana (still_Pd_Pt_soil)........20

Platinum and Palladium Soil Sample Anomalies, Stillwater Complex, Montana (still_anom)... 20

Trench and Bulk Sample Locations, Stillwater Complex, Montana (still_bulk).......................21

Drill-Holes, Stillwater Complex, Montana (still_sdh) ...........................................................21

Nickel-Copper Assay Data from Contact-Type Sulfide Exploration Projects (CuNi_

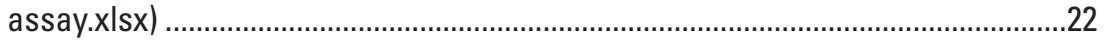

Exploration Trenches, Stillwater Complex, Montana (still_trenches)......................................23

J-M Reef, Stillwater Complex, Montana (jm_reef) ……......................................................23

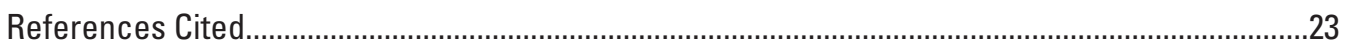

Appendix A—Lithologic Terminology Used for the Stillwater Complex ............................................26

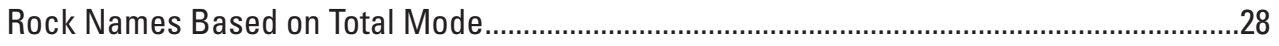




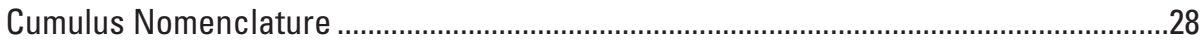

Traditional Rock Names Applied to Modes of Cumulus Minerals ...................................28

\section{Figures}

1. Geologic map and cross section of the Stillwater Complex, Montana ....................................2

2. Map showing the spatial extent of the geologic map databases included with this report....3

3. Stratigraphic column of the Stillwater Complex showing the proportion (percentage) of cumulus minerals............................................................................................................

4. Stratigraphic column of the Stillwater Complex showing differences in subdivisions and nomenclature

5. Maps showing the significant changes made to the geology in the southeastern part of the Stillwater Complex ..............................................................................................11

6. Map showing selected bulk sample sites in the Stillwater Complex .......................................14

7. Map showing selected drill-holes in the Stillwater Complex ..................................................14

8. Map showing surface grids generated from palladium and copper soil geochemistry data in the Stillwater Complex...............................................................................................17

\section{Tables}

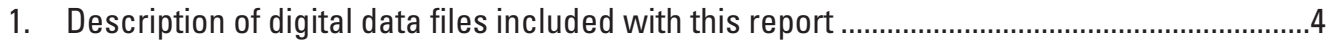

2. Polygon feature classes and possible attribute table fields ................................................

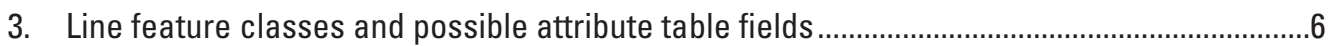

4. Structural measurement point feature classes and possible attribute table fields..................6

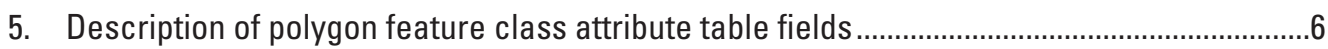

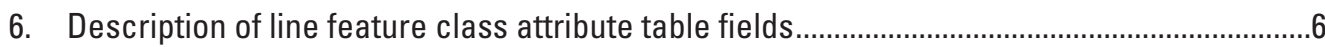

7. Description of point feature class attribute table fields with similar attribute table

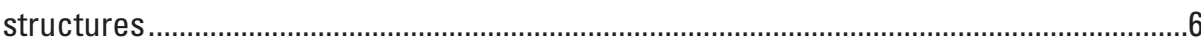

8. Summary of significant exploration and mining activities in the Stillwater Complex.............13

9. Exploration and mining companies that have conducted work in the Stillwater Complex ...15

10. Description of attribute table fields for the [still_mines] feature class...................................19

11. Description of attribute table fields for the [amax_soil_gchm] feature class .........................20

12. Description of attribute table fields for the [still_Pd_Pt_soil] feature class ...........................20

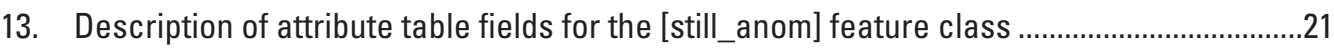

14. Description of attribute table fields for the [still_bulk] feature class .....................................21

15. Description of attribute table fields for the [still_sdh] feature class ......................................22

16. Definitions for column headings in the [CuNi_assay.xlsx] spreadsheet................................23

17. Description of attribute table fields for the [still_trenches] feature class .............................23

A1. Terminology used for cumulate igneous rocks of the Stillwater Complex ..............................27 


\section{Conversion Factors}

\begin{tabular}{lcll}
\hline \multicolumn{1}{c}{ Multiply } & \multicolumn{1}{c}{ By } & \multicolumn{1}{c}{ To obtain } \\
\hline foot $(\mathrm{ft})$ & 0.3048 & meter $(\mathrm{m})$ \\
mile $(\mathrm{mi})$ & 1.609 & kilometer $(\mathrm{km})$ \\
percent & 10,000 & parts per million $(\mathrm{ppm})$ or grams per metric ton $(\mathrm{g} / \mathrm{t})$ \\
\hline
\end{tabular}




\section{Acronyms and Abbreviations Used}

$\begin{array}{ll}\text { AMAX Inc. } & \begin{array}{l}\text { American Metal Climax Incorporated } \\ \text { ASCII }\end{array} \\ \text { Esri } & \begin{array}{l}\text { American Standard Code for Information Interchange } \\ \text { system software and geodatabase management applications } \\ \text { geographic coordinate system }\end{array} \\ \text { GCS } & \text { geographic information system } \\ \text { GIS } & \text { program to assist in compilation and publication of geologic maps } \\ \text { GSMAP } & \text { Johns-Manville Reef } \\ \text { J-M Reef } & \text { Montana Bureau of Mines and Geology } \\ \text { MBMG } & \text { North American Datum } \\ \text { NAD } & \text { platinum-group elements } \\ \text { PGE } & \text { platinum-group metals } \\ \text { PGM } & \text { parts per billion } \\ \text { ppb } & \text { parts per million } \\ \text { ppm } & \text { Stillwater PGM Resources } \\ \text { SPGMR } & \text { [U.S.] Bureau of Mines } \\ \text { USBM } & \text { U.S. Geological Survey } \\ \text { USGS } & \text { Universal Transverse Mercator } \\ \text { UTM } & \end{array}$

\section{Chemical Symbols Used}

$\begin{array}{ll}\mathrm{Cr} & \text { chromium } \\ \mathrm{Cu} & \text { copper } \\ \mathrm{Ni} & \text { nickel } \\ \mathrm{Pd} & \text { palladium } \\ \mathrm{Pt} & \text { platinum }\end{array}$

${ }^{1}$ The official name is "Bureau of Mines," without "U.S." or "United States," and USBM is unofficial, but for the convenience of the reader, and to avoid possible confusion with the National Bureau of Mines, "[U.S.] Bureau of Mines" and "USBM" are used in this report. 



\title{
A Geologic and Mineral Exploration Spatial Database for the Stillwater Complex, Montana
}

\author{
By Michael L. Zientek and Heather L. Parks
}

\section{Abstract}

The Stillwater Complex is a Neoarchean, ultramafic to mafic layered intrusion exposed in the Beartooth Mountains in south-central Montana. This igneous intrusion contains magmatic mineralization that is variably enriched in strategic and critical commodities such as chromium, nickel, and the platinum-group elements. One deposit, the J-M Reef, is the sole source of primary production and reserves for platinumgroup elements in the United States.

A large amount of information has been collected on the Stillwater Complex. In the 1930s, academics, the U.S. Geological Survey, and the [U.S.] Bureau of Mines initiated geologic investigations on the Stillwater Complex. Since that time, more than 600 publications on the Stillwater Complex have appeared in the scientific literature. Exploration and mining companies have collected even more information since the 1920s.

This report provides essential spatially referenced datasets based on geologic mapping and mineral exploration activities conducted from the 1920 s to the 1990s. This information will facilitate research on the complex and provide background material needed to explore for mineral resources and to develop sound land-management policy.

\section{Introduction}

The Neoarchean Stillwater Complex $(2,704 \pm 5 \mathrm{Ma}$, uranium-lead zircon; Premo and others, 1990) is a mafic to ultramafic intrusion exposed in the Beartooth Mountains in south-central Montana (fig. 1). Over 18,000 ft of layered igneous rocks are exposed and can be traced for 30 miles (mi) along strike. The J-M Reef, a reef-type platinum-group element (PGE) deposit, has been traced for 26 miles of the 30-mi strike-length of the complex, at least $1.2 \mathrm{mi}$ down the dip of layering, and is open at depth. As of 2014, the $\mathrm{J}$-M Reef is the sole source of primary PGE production and reserves in the United States. The Stillwater Complex also contains resources of chromium in stratiform chromite deposits and nickel and copper in contact-type PGE deposits (Zientek, 1993; Zientek and others, 2002).

This report contains digital representations of previously published U.S. Geological Survey (USGS) and Montana Bureau of Mines and Geology (MBMG) geologic maps of the Stillwater Complex, mineral exploration data compiled from many published and unpublished sources, and grid surfaces showing soil geochemical data. The exploration data only include activity that occurred before the early 1990s. The data are provided as 20 spatial database feature classes in an Esri geodatabase. Data on geologic unit (polygon); contacts, faults, and structures (line); and structure measurements (point), were sourced from four publications

- USGS Miscellaneous Investigation Series Map I-797 (Page and Nokleberg, 1974)

- USGS Miscellaneous Investigation Series Map I-1383 (Segerstrom and Carlson, 1982)

- Montana Bureau of Mines and Geology Special Publication 92 (Foose, 1985; Stillwater PGM Resources, 1985)

- USGS Open-File Report 93-207 (Zientek and others, 1993)

The map extent of the spatial datasets sourced from these geologic maps is shown in figure 2 .

Most of the exploration information collected by exploration companies after World War II is not in the public domain; the exceptions are records for the Anaconda Minerals Company, which are now available through the Anaconda Geological Documents Collection, American Heritage Center, University of Wyoming. Sources for the exploration data are listed in the metadata for each feature class file.

The intent of this report is to release digital data that can be used by scientists who are working on the Stillwater Complex. The data structure and data fields are described and defined, along with process steps that were used in creating the files. File and feature class names used in the text of this report are represented with bold text in square brackets (for example, [I797_poly]). Attribute table fields used in the text are represented with italics (for example, Unit_label). Detailed process steps used to create these files are discussed in the metadata for each feature class and in the "Description of Feature Classes Included with Stillwater_Complex.gdb" sections.

In addition to a description of the digital data, this report includes an overview of the geology and mineral exploration history that will help the user understand the information in the data files. 


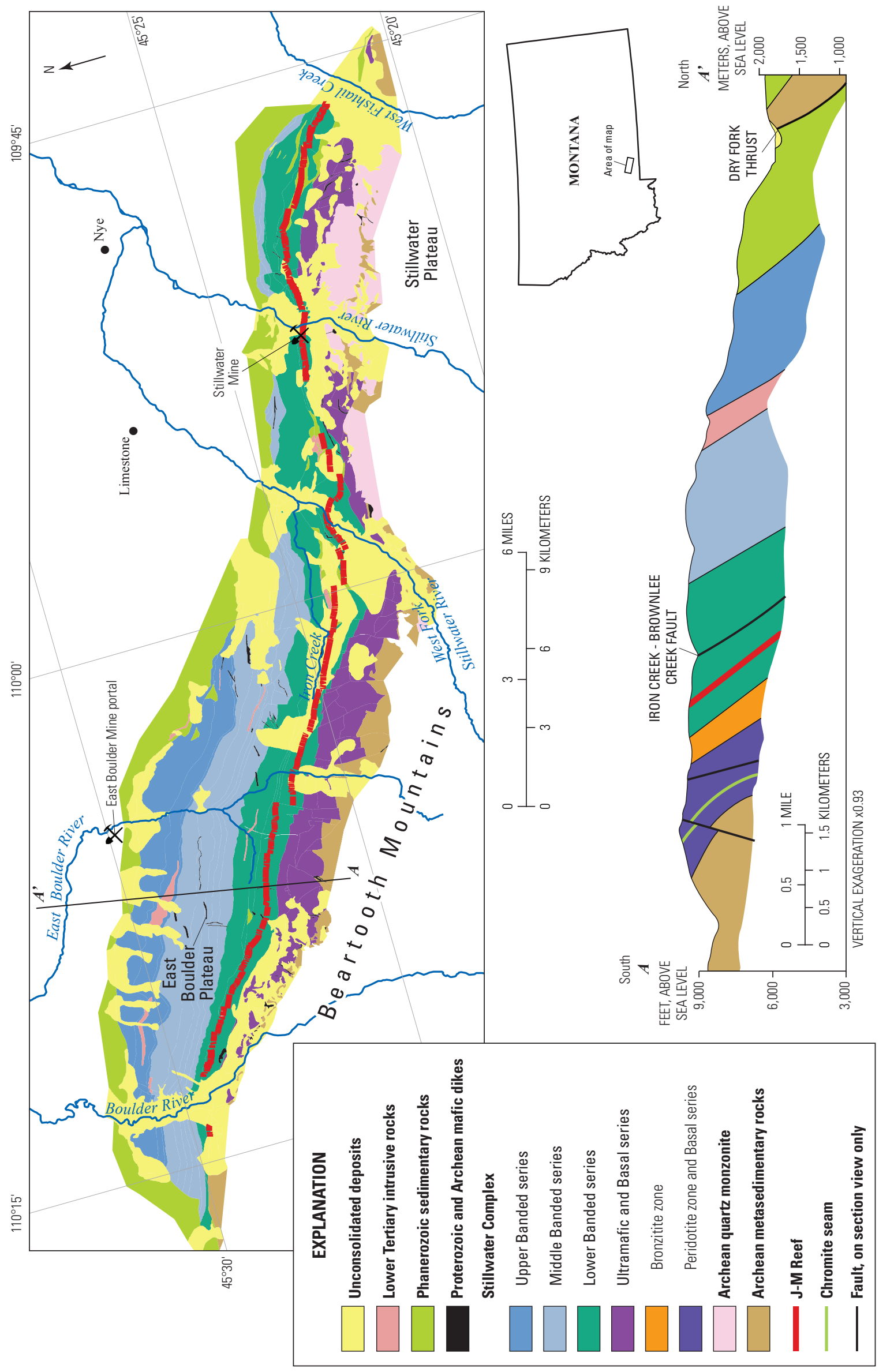

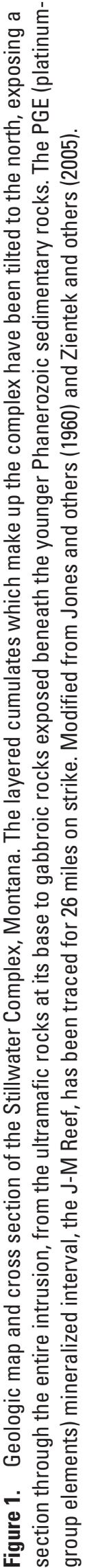



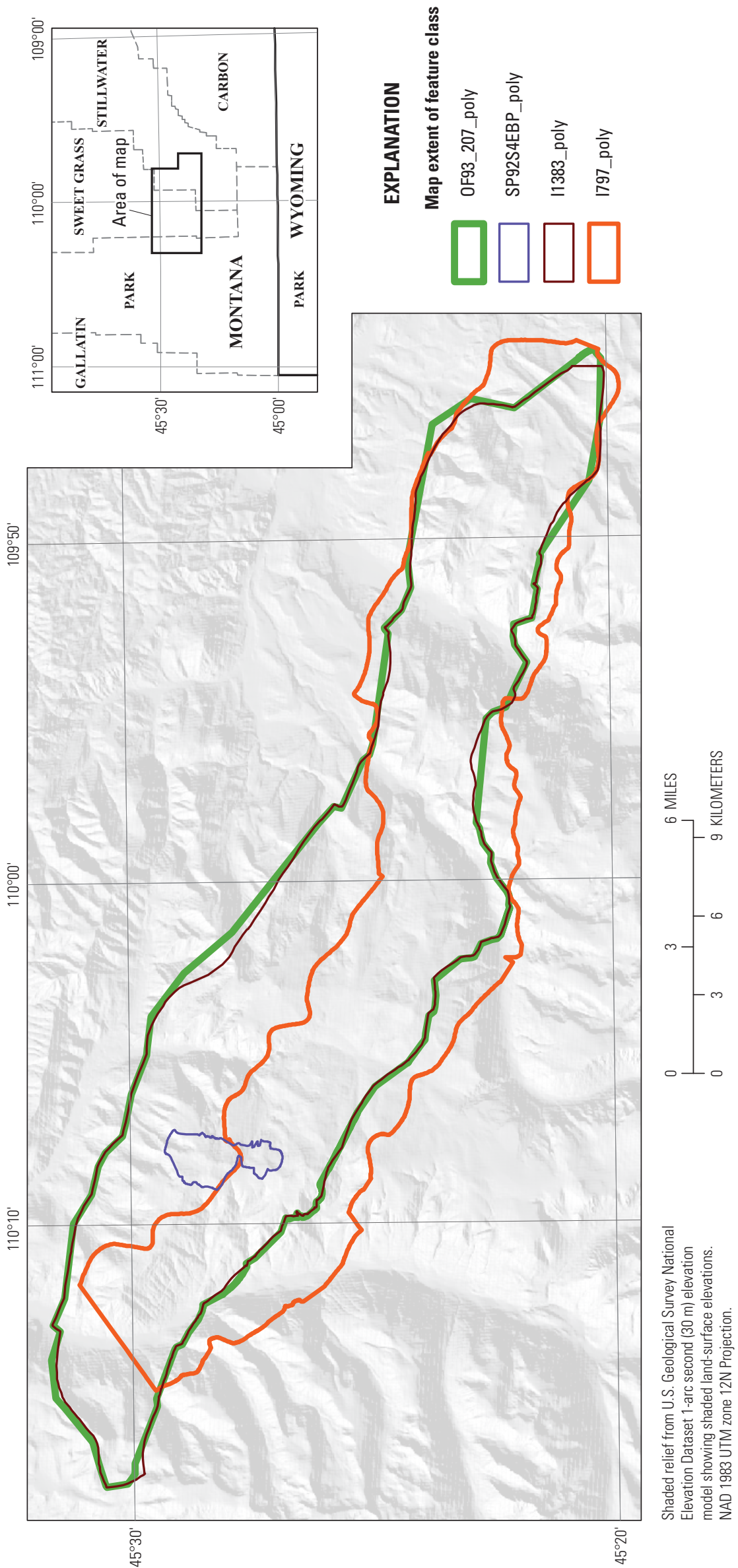

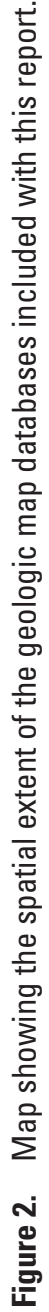




\section{Overview of Data Files}

The data files included with this report are briefly described in table 1 . The vector and grid spatial datasets are provided as Esri geodatabase feature classes and Esri grids. The spatial data are accompanied by symbolization (.lyr) and metadata files. Also included are Excel files with lithologic unit descriptions and nickel-copper assay data.

The attribute tables of the polygon, line, and structural measurement point files share several attributes in common and follow a parallel construction. The files and possible attribute fields are listed in tables 2-4; files containing a particular field show an $\mathrm{x}$ in the corresponding table cell. Attribute descriptions for the polygon, line, and point files are included in tables 5-7, respectively. The point files [amax_soil_gchm], [still_Pd_Pt_soil], [still_anom], [still_bulk], [still_sdh], and [still_trenches] have unique attribute table structures; therefore, each have a unique field description table, listed in the "Description of Feature Classes Included with Stillwater Complex.gdb-Exploration Datasets" section, which describes the fields contained within their attribute table.

Table 1. Description of digital data files included with this report.

[SPGMR, Stillwater PGM Resources]

\begin{tabular}{|c|c|}
\hline File or feature class name & File or feature class description \\
\hline [Stillwater_Complex.gdb] & $\begin{array}{l}\text { Geodatabase containing } 20 \text { feature classes of geologic, geochemical, and exploration related } \\
\text { information for the Stillwater Complex of southern Montana }\end{array}$ \\
\hline \multicolumn{2}{|r|}{ Esri polygon feature classes } \\
\hline$[$ I797_poly $]$ & $\begin{array}{l}\text { Geology of the southern part of the Stillwater Complex and adjacent rocks from Page and } \\
\text { Nokleberg (1974) }\end{array}$ \\
\hline$\left[\mathrm{I} 1383 \_\right.$poly $]$ & Geology of the Stillwater Complex from Segerstrom and Carlson (1982) \\
\hline [OF93_207_poly] & Geology of the Stillwater Complex from Zientek and others (1993) \\
\hline [SP92S3FP_poly] & Geology of Frog Pond area from SPGMR, (1985) \\
\hline [SP92S4EBP_poly] & Geology of East Boulder Plateau area from Foose (1985) \\
\hline \multicolumn{2}{|r|}{ Esri line feature classes } \\
\hline$[\mathrm{I} 1383$ line $]$ & Geologic contacts, faults, and structures from Segerstrom and Carlson (1982) \\
\hline [OF93_207_line] & Geologic contacts, faults, and structures from Zientek and others (1993) \\
\hline [SP92S4EBP_line] & East Boulder Plateau area faults and intrusions from Foose (1985) \\
\hline [still_trenches] & Exploration trenches \\
\hline$\left[j \mathrm{jm} \_\right.$reef] & Surface trace of J-M Reef (SPGMR, written commun., 1993) \\
\hline \multicolumn{2}{|r|}{ Esri point feature classes } \\
\hline [I797_point] & Geologic structural measurements sourced from Page and Nokleberg (1974) \\
\hline [still_anom] & Platinum and palladium soil sample anomalies (SPGMR, written commun., 1993) \\
\hline [still_bulk] & Trench and bulk sample locations \\
\hline [still_sdh] & Surface drill-holes \\
\hline \multicolumn{2}{|r|}{ Symbolization files for feature classes, based on Unit_label field } \\
\hline [I797_poly.lyr] & Symbolization for [I797_poly] feature class \\
\hline
\end{tabular}


Table 1.-Continued Description of digital data files included with this report.

[SPGMR, Stillwater PGM Resources]

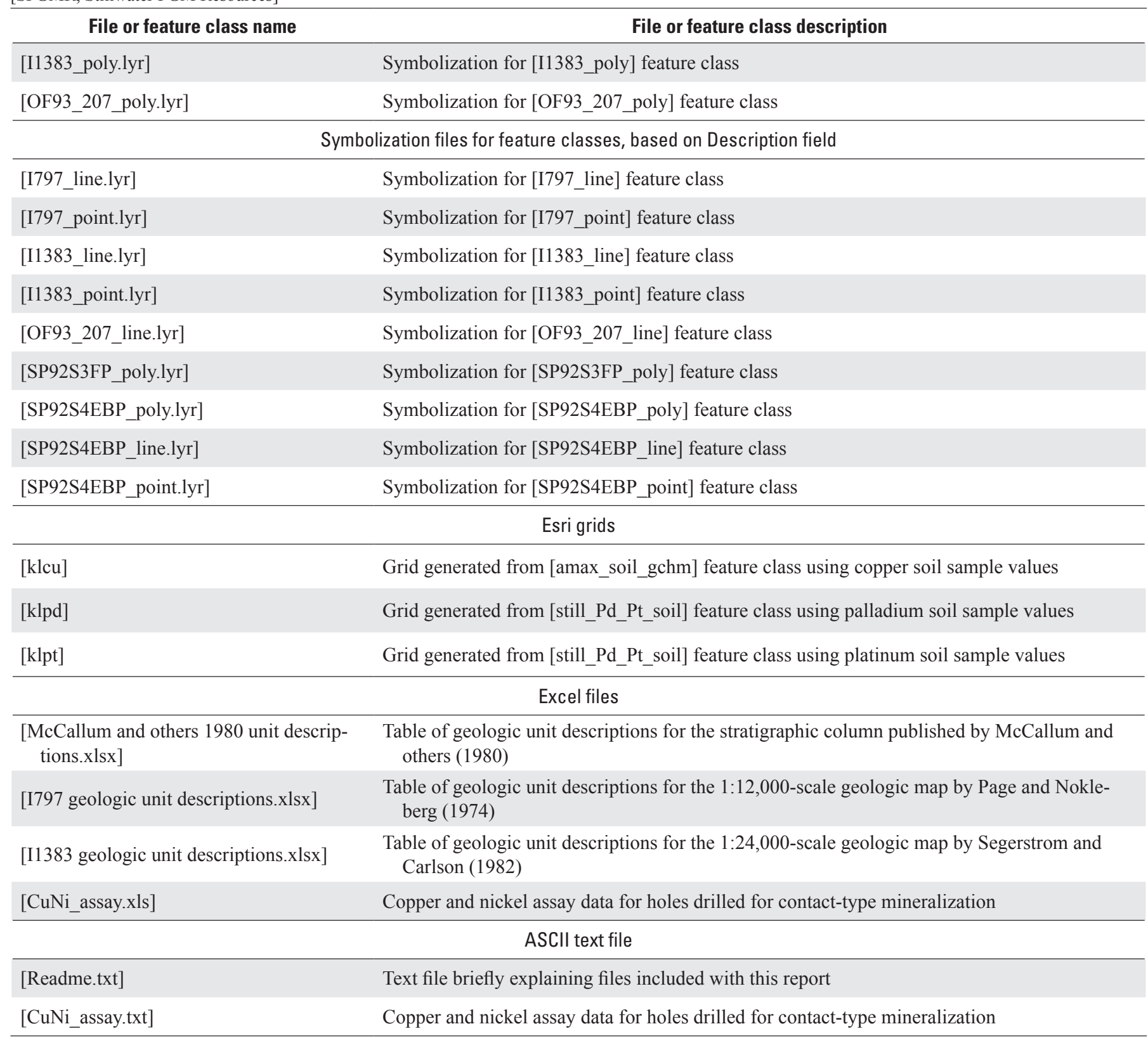

Table 2. Polygon feature classes and possible attribute table fields.

[x, files containing a particular field]

\begin{tabular}{|c|c|c|c|c|c|c|c|c|}
\hline Feature class name & Unit_label & Unit_1 & Unit_2 & Unit_3 & Descrption & Age & UntLbIConc & UnitConcld \\
\hline [I1383_poly] & $\mathrm{x}$ & $\mathrm{x}$ & $\mathrm{x}$ & $\mathrm{x}$ & $\mathrm{x}$ & $\mathrm{x}$ & & \\
\hline [OF93_207_poly] & $\mathrm{x}$ & $\mathrm{x}$ & $\mathrm{x}$ & $\mathrm{x}$ & $\mathrm{x}$ & $\mathrm{x}$ & $\mathrm{x}$ & $\mathrm{x}$ \\
\hline [SP92S3FP_poly] & & $\mathrm{x}$ & $\mathrm{x}$ & $\mathrm{x}$ & $\mathrm{x}$ & $\mathrm{x}$ & & \\
\hline [SP92S4EBP_poly] & & $\mathrm{x}$ & $\mathrm{x}$ & $\mathrm{x}$ & $\mathrm{x}$ & $\mathrm{x}$ & & \\
\hline
\end{tabular}


Table 3. Line feature classes and possible attribute table fields.

[x, files containing a particular field]

\begin{tabular}{lccc}
\hline \multicolumn{1}{c}{ Feature class name } & Description & Name & DirectKnwn \\
\hline [11383_line $]$ & $\mathrm{x}$ & $\mathrm{x}$ & $\mathrm{x}$ \\
[OF93_207_line $]$ & $\mathrm{x}$ & $\mathrm{x}$ & \\
{$[$ I797_line $]$} & $\mathrm{x}$ & $\mathrm{x}$ & \\
[SP92S4EBP_line $]$ & $\mathrm{x}$ & $\mathrm{x}$ & \\
{$[\mathrm{jm}$ reef $]$} & $\mathrm{x}$ & & \\
\hline
\end{tabular}

Table 4. Structural measurement point feature classes and possible attribute table fields.

[x, files containing a particular field]

\begin{tabular}{lcccc}
\hline \multicolumn{1}{c}{ Feature class name } & Descrption & Strike & Dip & Note \\
\hline [I797_point] & $\mathrm{x}$ & $\mathrm{x}$ & $\mathrm{x}$ & $\mathrm{x}$ \\
[I1383_point] & $\mathrm{x}$ & $\mathrm{x}$ & $\mathrm{x}$ & $\mathrm{x}$ \\
[SP92S4EBP_point] & $\mathrm{x}$ & $\mathrm{x}$ & $\mathrm{x}$ & \\
\hline
\end{tabular}

Table 5. Description of polygon feature class attribute table fields.

\begin{tabular}{ll}
\hline \multicolumn{1}{c}{ Field name } & \multicolumn{1}{c}{ Field description } \\
\hline Unit_label & Map unit label. \\
Unit_1 & In a hierarchical list, most general map unit name. \\
Unit_2 & In a hierarchical list, more specific map unit name. \\
Unit_3 & In a hierarchical list, most specific map unit name. \\
Description & Description of geologic unit. \\
Age & Age of geologic unit. \\
UntLblConc & Map unit label of rocks concealed by Quaternary cover. \\
UnitConcld & Name of geologic unit concealed by Quaternary cover. \\
\hline
\end{tabular}

Table 6. Description of line feature class attribute table fields.

\begin{tabular}{ll}
\hline \multicolumn{1}{c}{ Field name } & \multicolumn{1}{c}{ Field description } \\
\hline Description & Description of linear feature. \\
Name & Name of fault. \\
DirectKnwn & $\begin{array}{c}\text { 'Yes' if downthrown block is known, 'no' if downthrown block is } \\
\text { unidentified, 'NA' for not applicable. }\end{array}$ \\
\hline
\end{tabular}

Table 7. Description of point feature class attribute table fields with similar attribute table structures.

\begin{tabular}{ll}
\hline \multicolumn{1}{c}{ Field name } & \multicolumn{1}{c}{ Field description } \\
\hline Description & Description of structural measurement. \\
Strike & Strike azimuth, measured from 0 to 360 degrees. \\
Dip & Dip angle, in degrees below horizontal. -999 if unknown. \\
Note & Notes about structural measurement. \\
\hline
\end{tabular}




\section{Stillwater Complex-Rock Types and Geologic Map Units}

Layered intrusions, such as the Stillwater Complex (fig. 1), form by crystallization of magma deep in the earth's crust and have sheet-like to dike-like shapes. They consist primarily of cumulates, which are rocks that represent accumulations (concentrations) of early-formed cumulus minerals that crystallize from magmas. Cumulus rock textures are distinctive as they record nucleation and growth of crystals from the melt, enlargement of crystals to form a touching framework (a crystal mesh), solidification, and subsolidus grain boundary adjustments that minimize grain boundary surface energies (Hunter, 1987). Cumulus rock compositions are also distinctive because they do not represent the composition of naturally occurring magmas but instead can be understood as a mixture of early-formed crystals with different proportions of trapped liquid. Cumulus rock nomenclature is summarized in appendix A.

As magma crystallizes in layered intrusions, layering features develop that are recognized by variations in modal proportions of cumulus and intercumulus minerals, rock textures, grain size, and mineral compositions. Individual layers range from laminations formed by the orientation of individual crystals that are fractions of an inch in diameter to strata that are tens to hundreds of feet thick and may extend for hundreds of miles along strike. The layering features are so pronounced and consistent that stratigraphic principles developed for sedimentary rocks are applied to these igneous rocks. Geologists measure stratigraphic columns through the sequence of layered igneous rocks to define mappable units.

The layered rocks that make up the Stillwater Complex can be divided into a hierarchy of mappable stratigraphic units based on the proportions of minerals and sequences of rock types (fig. 3). The lower part of the stratigraphic section consists of ultramafic rocks; the upper part is made up of gabbroids. The names of the hierarchical levels of the map units vary by geologist. For some, it is "zone and member" (higher and lower); others use "series and zone." For this report, we have standardized the unit rank names using a "series-zone-subzone" convention. Accordingly, the stratigraphic section of Stillwater cumulate rocks are divided into five series, which are subdivided into 14 to 17 zones, depending on who did the work. Zones can be further subdivided into subzones. In some cases, members, cyclic units ${ }^{1}$, and marker layers are mapped.

Geologists generally agree on how to subdivide the ultramafic rocks in the lower part of the complex, although the unit names vary slightly. The Basal series is a laterally persistent but heterogeneous unit made up of bronzite-rich cumulates containing minor segregations of noncumulate mafic rock

\footnotetext{
${ }^{1}$ Cyclic (or rhythmic) units are characterized by a succession of layer types that repeat in a regular way stratigraphically.
}

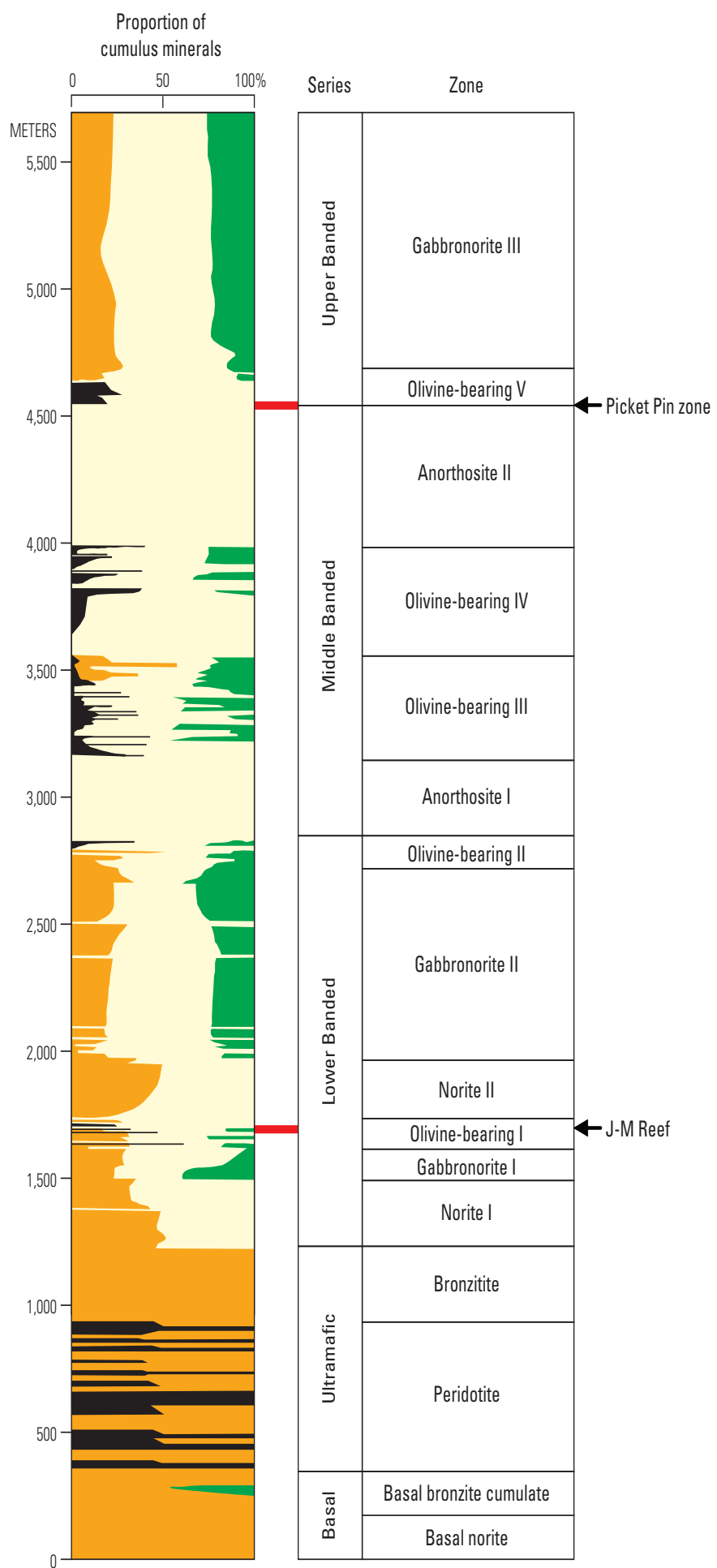

EXPLANATION

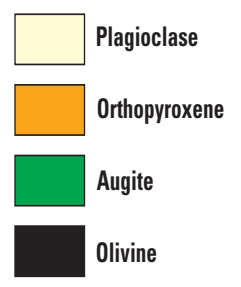

Figure 3. Stratigraphic column of the Stillwater Complex showing the percentage of cumulus minerals and the stratigraphic location of the Picket Pin zone and J-M Reef. Modified from McCallum and others (1980) and Raedeke and McCallum (1984). 
and inclusions of Archean metamorphosed sedimentary rocks (Page, 1979; Zientek, 1983; Zientek and others, 1985). The Ultramafic series is made up of rocks that contain cumulus olivine, orthopyroxene, and chromite and is subdivided into a lower Peridotite zone and an upper Bronzitite zone (Jackson, 1961; Raedeke and McCallum, 1984).

The presence (or absence) and proportion of cumulus orthopyroxene, augite, and olivine, as well as changes in apparent crystallization order, are the basis for the subdivision of the gabbroids into the Lower, Middle, and Upper Banded series (McCallum and others, 1980; Segerstrom and Carlson, 1982; Todd and others, 1982); cumulus plagioclase is present in all rocks in these series. Segerstrom and Carlson (1982) mapped 10 units (members) that they grouped into the Banded upper zone. McCallum and others (1980) and Raedeke (1982) described 12 units (zones) in a measured section on the East Boulder Plateau that they grouped into three units: the Lower Banded series, the Middle Banded series, and the Upper Banded series. The stratigraphic section of Todd and others (1982) consists of 14 units (zones). These subdivisions are compared in figure 4.

The most conspicuous difference in the stratigraphic descriptions is the subdivision of the Norite zone (member) of Segerstrom and Carlson (1982) into four stratigraphic units. As Segerstrom and Carlson were preparing their map, a stratabound layer of sulfide minerals enriched in platinumgroup elements, the J-M Reef, was being delineated within their Norite member by Johns-Manville Corp. (Page and others, 1985). A more refined subdivision of this part of the stratigraphic section was an essential element of the exploration process, as reflected in the reports by McCallum and others (1980) and Todd and others (1982). Most geologists have adopted the stratigraphic terminology based on the stratigraphic section (fig. 4) described by McCallum and others (1980) and (or) Todd and others (1982).

Stratigraphic descriptions of the Lower, Middle, and Upper Banded series as described by McCallum and others (1980) are included with this report as Excel file [McCallum and others 1980 unit descriptions.xlsx].

\section{Geologic Map of the Stillwater Complex, Montana (Page and Nokleberg, 1974)}

Page and Nokleberg (1974) conducted field work in the late 1960s, and compiled and published their map on a 1:12,000-scale USGS topographic base that was created in 1943 by stereophotogrammetric methods specifically for the Stillwater Complex. The 1943 USGS topographic maps correspond well with modern base materials so this geologic map works well as a foundation that can be revised with subsequent mapping. The Page and Nokleberg map covers the southern part of the complex as well as Archean metamorphosed sedimentary rocks and an Archean quartz monzonite suite that are adjacent to the complex. The Page and Nokleberg map incorporates work done by the
USGS and the [U.S.] Bureau of Mines (USBM) before and during World War II that mapped the chromite seams of the Ultramafic series and associated rocks at 1:1,200 (Peoples and Howland, 1940; Wimmler, 1948; Howland and others, 1949; Jackson and others, 1954; Peoples and others, 1954; Howland, 1955). The Page and Nokleberg map includes the results of some of the early nickel-copper exploration activities conducted along the basal contact of the complex, but most of that work was done after their map was compiled. The map does not show the full extent nor the subdivisions of the Lower, Middle, and Upper Banded series of the Stillwater Complex. A spatial database for this map has been previously released (Page and others, 2002) and is also included with this report as feature classes [I797_line], [I797_point], and [I797_poly].

Map unit descriptions for the 1:12,000-scale geologic map by Page and Nokleberg (1974) are included with this report as Excel file [I797 geologic unit descriptions.xlsx]. Map unit names and ranks have been standardized for this report and differ slightly from the source document.

\section{Geologic Map of the Banded Upper Zone of the Stillwater Complex and Adjacent Rocks (Segerstrom and Carlson, 1982)}

Segerstrom and Carlson (1982) focused on subdividing and mapping the gabbroids that overlie the Ultramafic series (their Upper Banded zone). The 1943 USGS topographic base used by Page and Nokleberg (1974) does not completely cover the Stillwater Complex and, at the time of the Segerstrom and Carlson (1982) compilation, 1:24,000scale topographic map coverage was not available for the complex. Therefore, the authors used a mosaic of parts of Mt. Rae and Tumble Mountain 1:24,000-scale maps along with a 1:24,000-scale photographic enlargement of the Mt. Wood and Mt. Douglas 1:62,500-scale topographic maps for their base map. Most of the Stillwater Complex lies on the photographically enlarged parts of the Mt. Wood and Mt. Douglas map sheets. For the lower part of the complex and adjacent rocks, Segerstrom and Carlson simplified the geologic map of Page and Nokleberg (1974) and re-compiled it on their base. They subdivided and mapped 10 units in the Lower, Middle, and Upper Banded series in the late 1970s. The stratigraphic units mapped by Segerstrom and Carlson (1982) are similar, but not identical, to those described by McCallum and others (1980). Segerstrom and Carlson's (1982) map does not show the subdivision of the Norite zone that hosts the J-M Reef. A digital representation of this map is included in this report as feature classes [I1383_line], [I1383_point], and [I1383_poly].

Map unit descriptions for the 1:24,000-scale geologic map by Segerstrom and Carlson (1982) are included with this report as Excel file [ $\mathbf{1 1 3 8 3}$ geologic unit descriptions.xlsx]. Map unit names and ranks have been standardized for this report and differ slightly from the source document. 


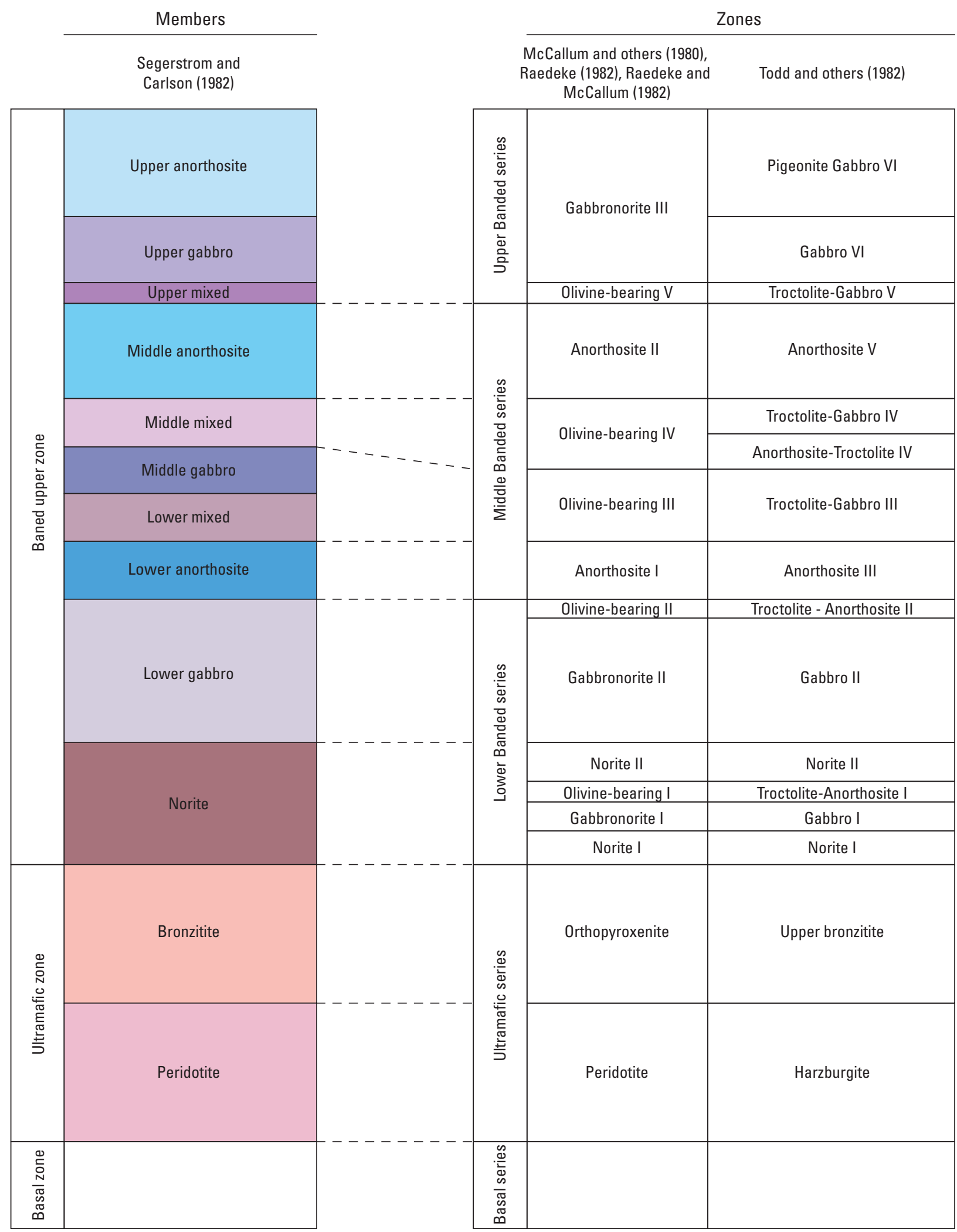

Figure 4. Stratigraphic column of the Stillwater Complex showing differences in subdivisions and nomenclature. In this database, the hierarchy of unit ranks used by Segerstrom and Carlson (1982) and earlier U.S. Geological Survey authors (zone, then member) is changed to the hierarchy used in newer publications (series, then zone). 


\section{Maps of the East Boulder Plateau (Montana Bureau of Mines and Geology Special Publication 92)}

Measured sections on the East Boulder Plateau document the stratigraphy of the Lower, Middle, and Upper Banded series (Hess, 1960; McCallum and others, 1980). Two maps of the plagioclase-bearing rocks of the East Boulder Plateau have been published (1) Foose (1985) published a 1:6,000scale map that includes rocks that extend from the contact between the Ultramafic and Lower Banded series to the contact between the Middle and Upper Banded series, and (2) a 1:6,000-scale outcrop map of rocks immediately adjacent to the J-M Reef (Stillwater PGM Resources, 1985). The base map used for both of these compilations is a 1:4,800-scale topographic map prepared by M\&I Consulting Engineers in 1980. Digital versions of both of these maps are presented in this report as feature classes [SP92S4EBP_line], [SP92S4EBP point], [SP92S4EBP_poly], and [SP92S3FP_poly].

\section{Mineral Resource Assessment of the Absaroka- Beartooth Study Area (Hammarstrom and others, 1993)}

In the early 1990s, the USGS conducted a mineral resource assessment of the Beartooth Study Area of the Custer and Gallatin National Forests in Montana, which includes the Stillwater Complex (Hammarstrom and others, 1993). The assessment scale was 1:126,720 - a half-inch to a mile. Segerstrom and Carlson's (1982) map was used for the assessment; however, the spatial accuracy of the 1930s-era 1:62,500-scale topographic maps that served as the base for compilation limited the utility of this map for detailed studies. The geologic map by Segerstrom and Carlson (1982) was revised and simplified for use at a scale of 1:100,000 for the assessment study. The geology of the Lower and Middle Banded series was significantly revised between the Stillwater River and West Fishtail Creek. Analysis of detailed measured sections in the eastern part of the Stillwater Complex (work conducted in the late 1980s and published by Peterson and others, 1995) clarified the stratigraphy of the Lower and Middle Banded series in this area (fig. 5). Using his field notes, R.R. Carlson revised the geologic map in this area. Other revisions to the overall map included (1) continuing high-angle-thrust faults in areas of cover and (2) adjusting some contacts to match large offsets in the J-M Reef. The map was generalized for use at a scale of 1:100,000 by (1) deleting small polygons of mafic dikes that cut the complex, (2) grouping units, (3) drawing larger polygons to include clusters of smaller polygons of similar rock type, (4) deleting sackung ${ }^{2}$, and (5) deleting fault segments that show little or no offset when viewed at a scale of $1: 100,000$.

${ }^{2} \mathrm{~A}$ ridge-parallel trough formed by surficial creep, believed in some cases to be activated by earthquake shaking (American Geosciences Institute, 2014).

\section{Description of Feature Classes in Stillwater_Complex.gdb_Geologic Maps}

\author{
Feature Classes from Page and Nokleberg (1974) \\ (I797_poly, I797_line, 1797_point)
}

USGS Miscellaneous Investigation Series Map I-797 (Page and Nokleberg, 1974) publication was used as a source for three feature classes included with this report: [I797_ poly], [1797_line], and [I797_point]. The [I797_poly] polygon feature class contains spatial and descriptive data for the geology of the Stillwater Complex. The [1797_line] line feature class contains spatial and descriptive data for geologic contacts, faults, and linear geologic structures. The [I797_point] point feature class contains spatial and descriptive data for structural measurements of the Stillwater Complex. The geologic units are described in the excel file [I797 geologic unit descriptions.xlsx], and are also briefly described in the attribute table of the feature class. The Unit label field in the [I797_poly] feature class correlates with the Unit label column in the [1797 geologic unit descriptions.xlsx] file. References used in the [I797 geologic unit descriptions.xlsx] file are listed on the "References" tab in the Excel spreadsheet.

These datasets were created by digitizing the geologic features shown on the 1:12,000-scale Page and Nokleberg (1974) geologic map. The published paper geologic map sheets were scanned by Optronics Speciality Corp., Inc. (Northridge, Calif.). The digital files were georeferenced and transformed to the Montana State Plane coordinate system. The data was digitized on-screen using heads up digitizing and an interim geologic map data model was applied. The data were then checked for position and attribute accuracy by comparing plots of the digital data to the source maps. The attribute table was configured to conform to a unified data structure. The file was reprojected to Universal Transverse Mercator (UTM) Zone 12N NAD 1983 and converted from an ArcInfo coverage to a geodatabase feature class. A topology was created for the line and polygon files with the polygon topological rules (1) must not have gaps, (2) must not overlap, and (3) boundary must be covered by [1797_line]; and line topological rules (1) must not overlap, and (2) must not self-overlap. The topology was verified and errors were corrected where needed. These datasets are not meant to be displayed at larger than 1:12,000.

The attribute tables were constructed to reflect a unified field structure for the polygon, line, and structural measurement point feature classes included with this report. User defined attribute table fields included within these files are shown in tables 2 (polygons), 3 (lines), and 4 (points), and their descriptions are listed in tables 5 ([1797_poly]), 6 ([1797_line]), and 7 ([1797_point]). 


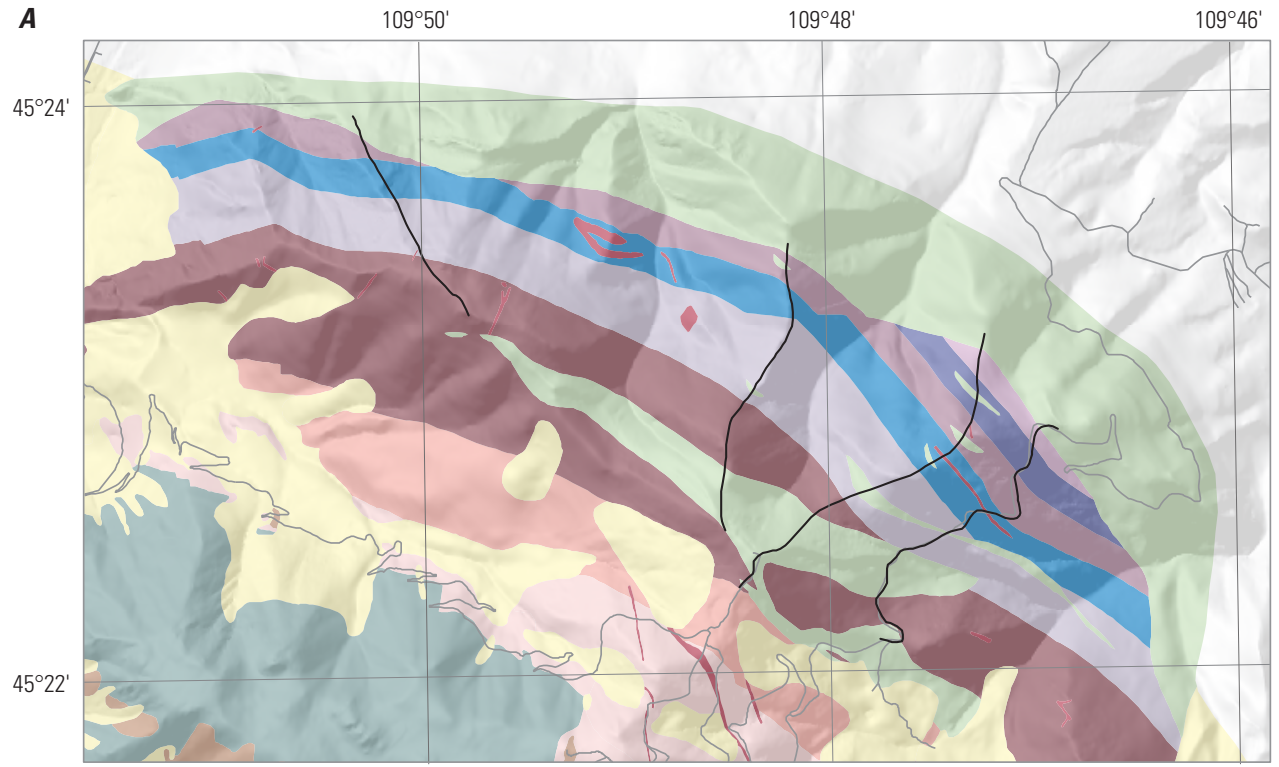

\begin{tabular}{|c|c}
\hline & EXPLANATION \\
\hline Oal & Quaternary deposits \\
\hline Pzs & Sedimentary rocks \\
\hline PAmi & Mafic intrusive rocks \\
\hline Aqm & Granitic intrusive rocks \\
\hline Amm & Stillwater Complex \\
\hline Amg & Middle Banded series \\
\hline Alm & Middle mixed zone \\
\hline Ala & Middle gabbro zone \\
\hline
\end{tabular}

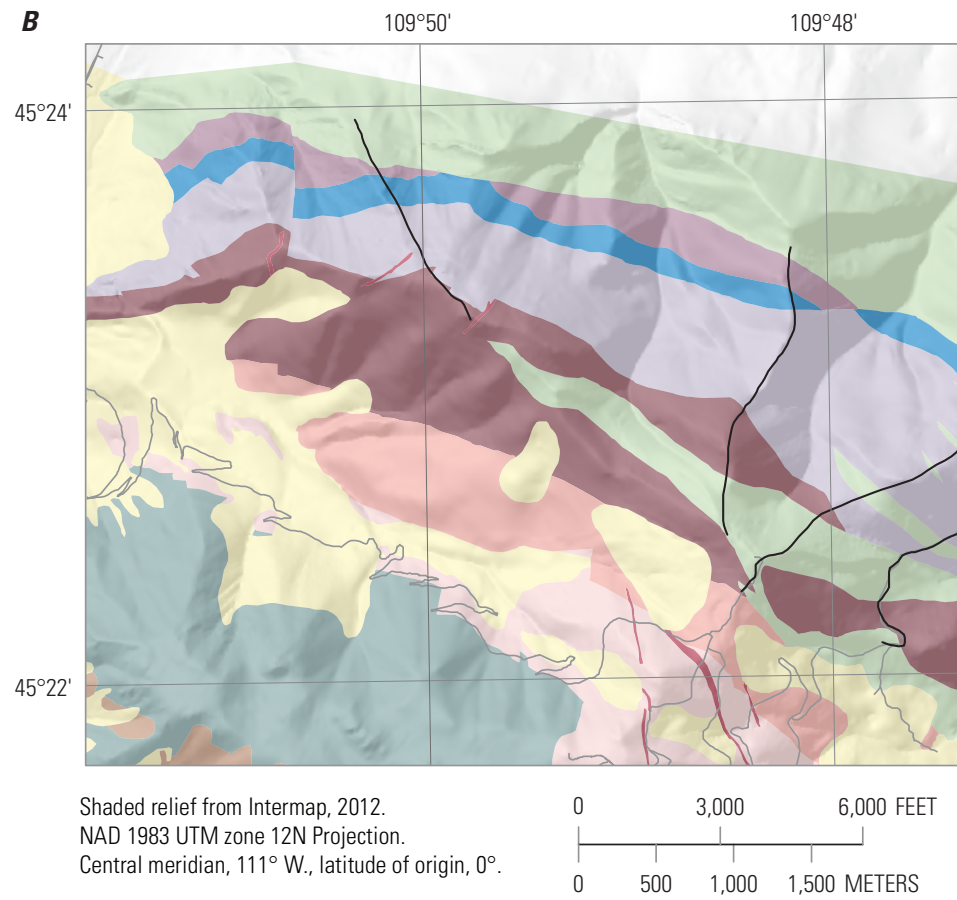

Lower Banded series

\begin{tabular}{|c|c|}
\hline Alg & Lower gabbro zone \\
\hline An & Norite zone \\
\hline Aub & $\begin{array}{c}\text { Bronzitite zone of the } \\
\text { Ultramafic series }\end{array}$ \\
\hline Apb & $\begin{array}{c}\text { Peridotite zone of the } \\
\text { Ultramafic series and } \\
\text { Basal bronzite cumulate } \\
\text { and Basal norite zones } \\
\text { of the Basal series }\end{array}$ \\
\hline
\end{tabular}

Metamorphic rocks, quartz monzonite, hornfels, and granite

Section line

Road

AAD 1983 UTM

Central meridian, $111^{\circ} \mathrm{W}$., latitude of origin, $0^{\circ}$

$\begin{array}{llll}0 & 500 & 1,000 & 1,500 \\ & \text { METERS }\end{array}$

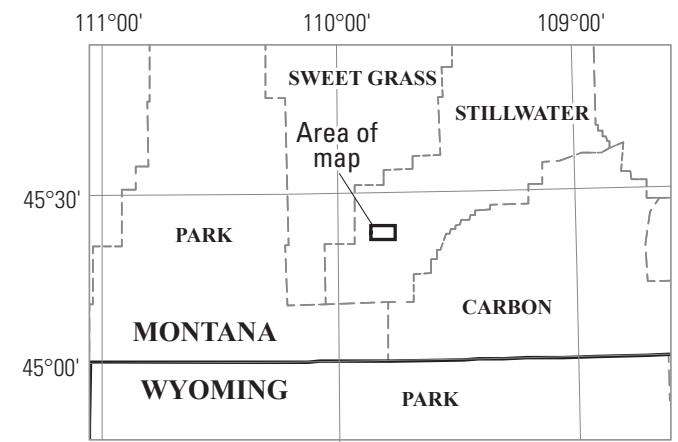

Figure 5. Maps showing the significant changes made to the geologic mapping in the southeastern part of the Stillwater Complex. (A) Geology as mapped from Segerstrom and Carlson (1982); (B) Geology as mapped from Zientek and others (1993). Section lines from Peterson and others (1995). 


\section{Feature Classes from USGS Miscellaneous Investigation Series I-1383 (I1383_poly, I1383_ line, I1383_point)}

USGS Miscellaneous Investigation Series Map I-1383 (Segerstrom and Carlson, 1982) was used as a source for three feature classes included with this report: [I1383_poly], [I1383_line], and [I1383_point]. The [I1383_poly] polygon feature class contains spatial and descriptive data for the geology of the Stillwater Complex. The [I1383_line] line feature class contains spatial and descriptive data for geologic contacts, faults, and linear geologic structures. The [I1383_point] point feature class contains spatial and descriptive data for structural measurements of the Stillwater Complex. The geologic units are described in the Excel file [I1383 geologic unit descriptions.xlsx], and are also briefly described in the attribute table of the feature class. The Unit label field in the [11383_poly] feature class correlates with the Unit label column in the [ $\mathbf{1 1 3 8 3}$ geologic unit descriptions.xlsx] file. References used in the [I1383 geologic unit descriptions.xlsx] file are listed on the "References" tab in the Excel spreadsheet.

These datasets were created by digitizing the geologic features shown on the 1:24,000-scale Segerstrom and Carlson (1982) geologic map. The geologic map was scanned and georeferenced and the features were digitized by East View Cartographic. The file was reprojected to UTM Zone 12N NAD 1983. Features were then checked against the georeferenced source map and edits were made as necessary. A topology was created for the line and polygon files with the polygon topological rules (1) must not have gaps, (2) must not overlap, and (3) boundary must be covered by [ $\mathbf{1 1 3 8 3}$ line]; and line topological rules (1) must not overlap, and (2) must not self-overlap. The topology was verified and errors were corrected where needed. These datasets are not meant to be displayed at larger than 1:24,000.

The attribute tables were constructed to reflect a unified field structure for all the polygon, line, and structural measurement point feature classes included with this report. User defined attribute table fields included within these files are shown in tables 2 (polygons), 3 (lines), and 4 (points), and their descriptions are listed in tables 5 ([I1383_poly]), 6 ([I1383_line]), and 7 ([I1383_point] $]$ ).

\section{Feature Classes from USGS Open-File Report 93-207 (OF93_207_poly, 0F93_207_line)}

USGS Open-File Report 93-207 (Zientek and others, 1993) was used as a source for two feature classes included with this report: [OF93_207_poly], and [OF93_207_line]. The [OF93_207_poly] polygon feature class contains spatial and descriptive data for the geology of the Stillwater Complex. The [OF93_207_line] line feature class contains spatial and descriptive data for geologic contacts, faults, and linear geologic structures.
These datasets are largely based on the geologic map by Segerstrom and Carlson (1982). The map was generalized for use at a scale of 1:100,000 and significant revisions were made to the geology of the Banded series in the area between the Stillwater River and West Fishtail Creek. The Segerstrom and Carlson (1982) geologic map was digitized and minimally attributed using the GSMAP program (Selner and Taylor, 1992). The resultant digital map was then revised, generalized, and converted into an ASCII file and then brought into an Esri ArcInfo data format to create an ArcInfo coverage. The Department of Geography at the University of Idaho corrected polygon errors in the ArcInfo coverage, attributed all polygons with minimal geologic map unit information, and added a boundary for the outer extent of the mapped units. The digital files were revised and attributed using an interim USGS geologic map data model. The data were checked for accuracy by comparing plots of the digital data to the source map. The files were converted from coverages into geodatabase feature classes. A topology was created for the files with the polygon topological rules (1) must not have gaps, (2) must not overlap, and (3) boundary must be covered by [OF93_207_line]; and line topological rules (1) must not overlap, and (2) must not self-overlap. The topology was verified and errors were corrected where needed. These datasets are not meant to be displayed at larger than 1:100,000.

The attribute tables were constructed to reflect a unified field structure for all of the polygon and line feature classes included with this report. User defined attribute table fields included within these files are shown in tables 2 (polygons) and 3 (lines), and their descriptions are listed in tables 5 ([OF93_207_poly]) and 6 ([OF93_207_line]).

\section{Feature Classes from Montana Bureau of Mines and Geology Special Publication 92 (SP92S3FP poly, SP92S4EBP_poly, SP92S4EBP_line, SP92S4EBP_point)}

Montana Bureau of Mines and Geology Special Publication 92 (Foose, 1985, and Stillwater PGM Resources, 1985) was used as a source for four feature classes included with this report: [SP92S3FP_poly], [SP92S4EBP_poly], [SP92S4EBP_line], [SP92S4EBP_point]. The [SP92S3FP_ poly] polygon feature class contains spatial and descriptive data for the geology of the Frog Pond area of the Stillwater Complex (LeRoy and others, 1985). The [SP92S4EBP_poly] polygon feature class contains spatial and descriptive data for the geology of the East Boulder Plateau area of the Stillwater Complex. The [SP92S4EBP_line] line feature class contains spatial and descriptive data for faults and linear geologic structures. The [SP92S4EBP_point] point feature class contains spatial and descriptive data for structural measurements of the East Boulder Plateau area of the Stillwater Complex.

These datasets were created by digitizing the geologic features shown on the 1:6,000-scale geologic maps by Foose (1985) and Stillwater PGM Resources (1985). The geologic 
maps were scanned and georeferenced and the features were digitized on-screen using a GIS. Features were checked against the georeferenced source maps and edits were made as necessary. A topology was created for the line and polygon files with the polygon topological rules (1) must not have gaps and (2) must not overlap, and line topological rules (1) must not overlap and (2) must not self-overlap. The topology was verified and errors were corrected where needed. These datasets are not meant to be displayed at larger than 1:6,000.

The attribute tables were constructed to reflect a unified field structure for all the polygon, line, and structural measurement point feature classes included with this report. User defined attribute table fields included within these files are shown in tables 2 (polygons), 3 (lines), and 4 (points), and their descriptions are listed in tables 5 ([SP92S3FP poly] $]$ and ([SP92S4EBP_poly]), 6 ([SP92S4EBP_line]), and 7 ([SP92S4EBP_point]).

\section{Exploration-Related Spatial Datasets}

The Stillwater Complex hosts mineral occurrences and deposits enriched in nickel, copper, chromium, and platinumgroup elements (PGE) that form by segregation and accumulation of crystals of metallic oxides or immiscible sulfide liquids from silicate magma. Sulfide-associated mineralization includes (1) contact-type sulfide deposits (magmatic sulfide minerals concentrated near the base of the complex; Zientek, 2012), (2) reef-type mineralization (stratiform concentrations of disseminated sulfide minerals that may be enriched in PGE; Zientek, 2012), (3) sulfide and PGE concentrations occurring at and significantly below medium-grained anorthosites overlying coarse-grained anorthosites that make up the Anorthosite II zone (the Picket Pin zone described by Boudreau and McCallum, 1986), and (4) pegmatoidal lenses, pipes, and other discordant mineralization. Oxide-associated mineralization includes (1) chromitites (stratiform chromitite layers; Schulte and others, 2012), and (2) PGE-enriched stratiform chromitite layers (Zientek, 2012).

Exploration to assess the mineral potential of the Stillwater Complex started in the late 1880's and continues today (table 8). Work typically began with reconnaissance mapping, geochemical sampling, and geophysical investigations to identify areas to be tested by bulk sampling, trenching, drilling, or underground exploration. The amount of data that has been generated is staggering; however, it is not easy to find and is difficult and expensive to capture in a form that can be manipulated in a geographic information system.

This report does not include all of the data from the exploration process. It includes spatial digital datasets created from both published and unpublished sources that are (1) representative of the latter stages of the exploration process; (2) give an indication of the location, quantity, and quality of mineralization; or (3) contain geochemical information. Location of bulk sample sites and trenches ([still_bulk] and [still_trenches]) and surface drill-hole collars ([still_sdh]) clearly show the level of exploration activity (figs. 6 and 7). Bulk sample sites and trenches show where significant mineralization was observed on the ground. The density of drilling provides an indication of areas that are prospective and where resources have been identified. The point spatial digital datasets [amax_soil_gchm] and [still_Pd_Pt_soil] show locations

Table 8. Summary of significant exploration and mining activities in the Stillwater Complex.

\begin{tabular}{|c|c|c|c|}
\hline Target & Initial discovery & Major exploration activity & Mining activity \\
\hline $\begin{array}{l}\mathrm{Ni}-\mathrm{Cu} \text { deposits- } \\
\text { higher grade } \\
\text { resources }\end{array}$ & 1885 & $\begin{array}{l}\text { Initial examination by Anaconda in 1925; drilling } \\
\text { by Anaconda in 1937; drilling and metallurgi- } \\
\text { cal testing by USBM from } 1939 \text { to } 1942 .\end{array}$ & None \\
\hline $\begin{array}{l}\mathrm{Ni}-\mathrm{Cu} \text { deposits- } \\
\text { bulk mineable } \\
\text { resources. }\end{array}$ & 1885 & $\begin{array}{l}\text { Major expansion of delineated resources and } \\
\text { discovery of new occurrences by Anaconda, } \\
\text { AMAX Inc., Cyprus, and Lindgren from } 1966 \\
\text { until 1982. PGE potential assessed starting in } \\
\text { the 1980s by USGS and others. }\end{array}$ & None \\
\hline Chromite seams & $\sim 1890$ & $\begin{array}{l}\text { Geologic mapping, trenching, drilling, and metal- } \\
\text { lurgical testing by USGS and USBM from } \\
1939 \text { to } 1942 \text {; Anaconda in 1979; Chrome } \\
\text { Corp. in } 1989 .\end{array}$ & $\begin{array}{l}\text { Limited mining from } 1905 \text { to 1918; some } \\
\text { production during WWII; most produc- } \\
\text { tion from Mouat-Sampson Mine from } \\
\text { 1953-1962. }\end{array}$ \\
\hline J-M Reef (PGE) & $\begin{array}{l}\text { Potential recognized } \\
\text { in 1936. J-M Reef } \\
\text { discovered in } \\
1973 .\end{array}$ & $\begin{array}{l}\text { Johns-Manville beginning in 1967; Anaconda be- } \\
\text { ginning in 1977; surface exploration essentially } \\
\text { complete by the early 1990s. }\end{array}$ & $\begin{array}{l}\text { Stillwater Mine started in 1986; East Boul- } \\
\text { der Mine in } 2001 .\end{array}$ \\
\hline $\begin{array}{l}\text { Picket Pin zone } \\
\quad \text { (PGE) }\end{array}$ & $\begin{array}{l}\text { Occurrence described } \\
\text { in } 1936 .\end{array}$ & $\begin{array}{l}\text { Anaconda from } 1979 \text { to } 1982 \text {. International Plati- } \\
\text { num in the late } 1980 \mathrm{~s} \text {. }\end{array}$ & None \\
\hline $\begin{array}{l}\text { PGE-enriched } \\
\text { chromite seams }\end{array}$ & $\begin{array}{l}\text { Described by USGS } \\
\text { in mid 1970s. }\end{array}$ & $\begin{array}{l}\text { Anaconda from } 1977 \text { to } 1979 \text {; Boulder Gold and } \\
\text { Chrome Corp. in the 1980s. }\end{array}$ & None \\
\hline
\end{tabular}




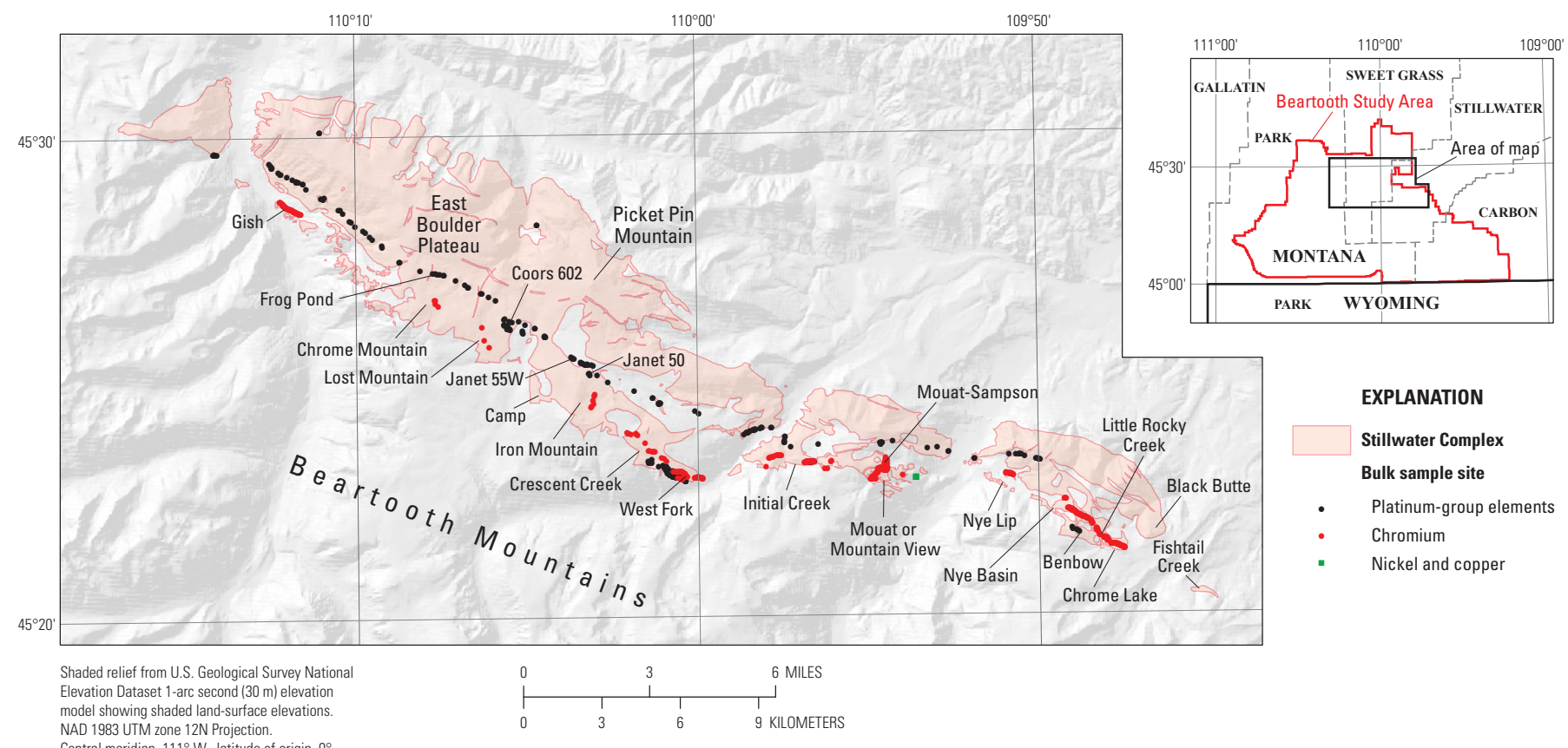

Figure 6. Map showing selected bulk sample sites in the Stillwater Complex. Geographic areas discussed in text are labeled.

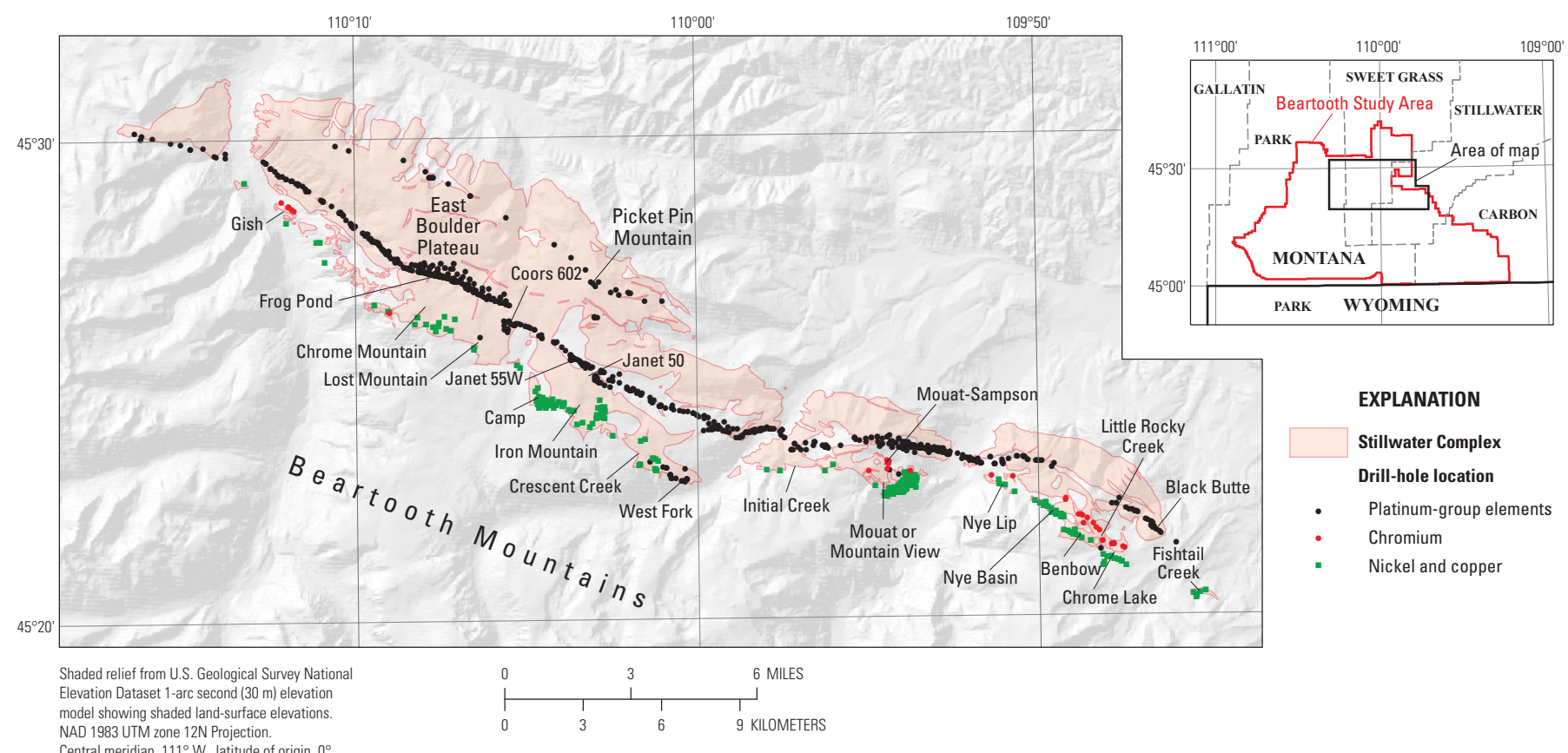

Figure 7. Map showing selected surface drill-hole collar locations in the Stillwater Complex. Geographic areas discussed in text are labeled. 
of soil samples taken and analyzed to identify geochemical anomalies. The [still_anom] dataset and the grids [klpd] and [klpt] highlight the results of platinum and palladium soil geochemical surveys that identified the J-M Reef and smaller mineralized pegmatoids.

Only underground mining has been conducted at Stillwater and mine portals and adits can be observed on the digital orthophoto quads, the digital raster graphic 7.5-minute topographic maps, and some geologic maps (Peoples and Howland, 1940; Jackson and others, 1954; Peoples and others, 1954). The location of mine tunnels, shafts, adits, and portals are compiled in the feature class [still mines].

Roby (1949), Wimmler (1948), Jackson (1968), Conn (1979), Page and others (1985), Zientek (1993), and Zientek and others (2002) have presented overviews of exploration work in the Stillwater Complex. Exploration companies that have done work include those listed in table 9. The following summary is provided to give context to the information in the spatial digital datasets. The discussion is organized by exploration target, which usually corresponds to different deposit types.

\section{Nickel and Copper in Contact-Type Deposits}

Nickel-copper mineralization was discovered in the 1880s in the eastern part of the Stillwater Complex. Starting in 1925, several companies conducted exploration programs to characterize the nickel and copper resources near the base of the complex (Page and others, 1985). Almost all of the rocks along the base of the complex have been examined by methods that include geologic mapping at scales ranging from $1: 1,200$ to $1: 12,000$, aeromagnetic surveys (Blakely, 1984), soil geochemical surveys (for example, [amax_soil_gchm]), and ground-based geophysical surveys (most are typically magnetics and induced polarization). Bulldozer trenching was done in the Benbow area (locations of 12 trenches totaling 6,400 ft excavated by Anaconda in 1969 are shown in the [still_trenches] feature class), drilling was done in most places, and exploratory adits were driven in the Nye Basin and Mountain View areas. Metallurgical test work was conducted on mineralized rocks from the Mouat and Camp deposits and from the Nye Basin and Chrome Lake prospects. Drill-hole collar locations are compiled in the feature class [still_sdh] (fig. 7). The drill-hole patterns show that most exploration

Table 9. Exploration and mining companies that have conducted work in the Stillwater Complex.

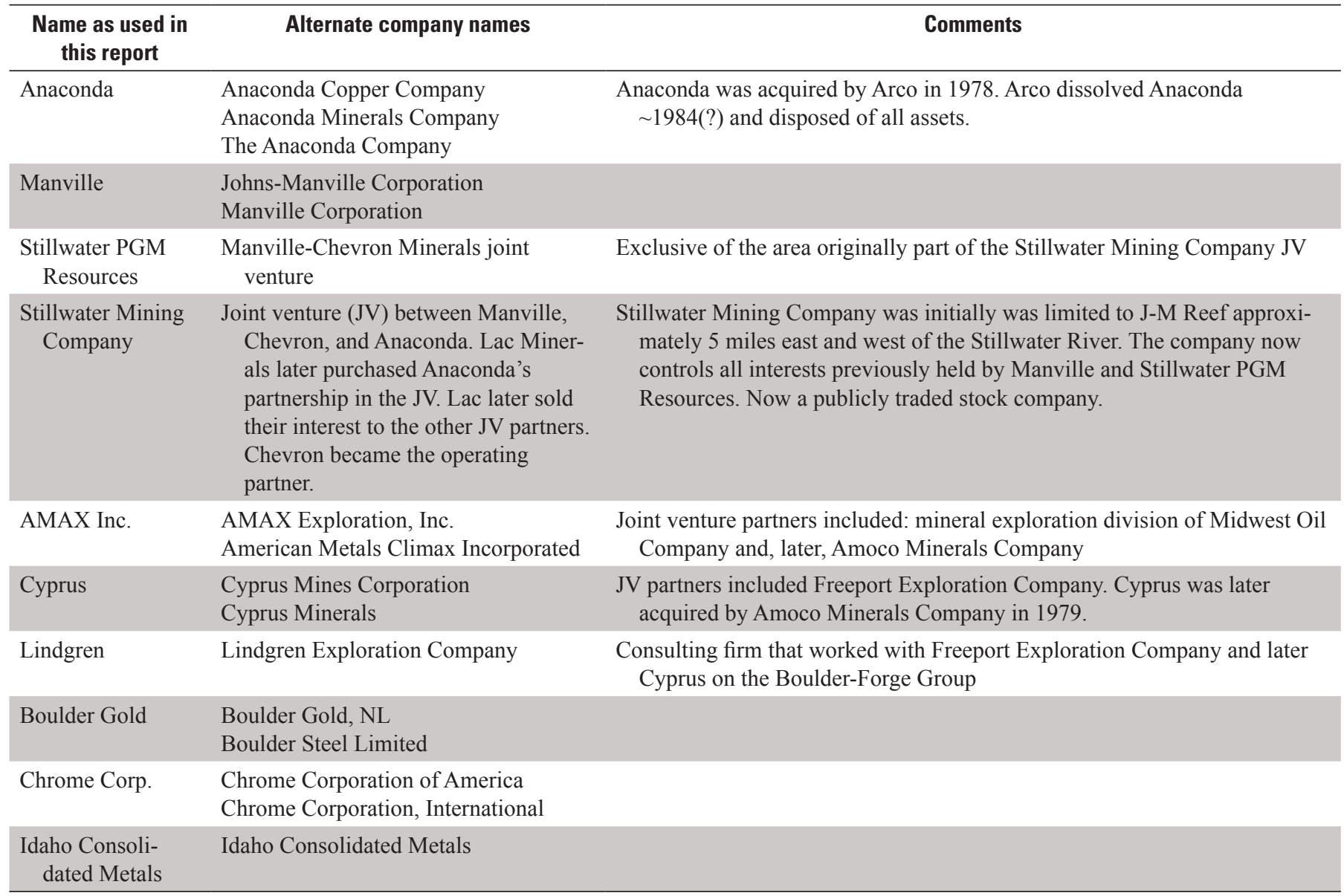


work for nickel and copper in contact-type deposits was in the eastern part of the complex; the density of drilling shows the location of the Mouat nickel-copper deposit in the Mountain View area (Zientek and others, 1989). and the Camp nickelcopper deposit in the Iron Mountain area. Both of these areas were drilled in sufficient detail to calculate a mineral inventory. Data for six holes drilled by Lindgren for Cyprus on the Boulder-Forge claim group in 1969 and 2 to 3 holes drilled in the Mouat nickel-copper deposit by Idaho Consolidated Metals in 2000 are not included in the compilation.

A grid [klcu] representing the copper results of a soil geochemical survey conducted by AMAX Inc., was generated from the [amax_soil_gchm] feature class (fig. 8). The grid was calculated using the log-transformed values of copper using the ordinary kriging method with a spherical semivariogram model. A variable search radius and 12 points were used. The grid was generated with the spatial analyst extension in Esri ArcGIS 8.3 and was clipped by a polygon to limit the analysis to the areas that were sampled.

\section{Chromium-The G and H Chromite Seams}

In the Stillwater Complex, chromite seams are found in the Peridotite zone of the Ultramafic series, and only the chromite-enriched layers in the Mountain View, Nye Basin, Benbow, and Gish areas have the continuity, thickness, and grade to be of economic interest for chromium. Stillwater chromite mineralization is similar to, but lower-grade than, high-iron or chemical grade chromite ores mined elsewhere in the world (Jackson, 1968; Zientek, 1993).

Chromite seams were discovered early in the exploration of the Stillwater Complex (Page and others, 1985). As many as 13 chromite seams ${ }^{3}$ are present within the Peridotite zone, but chromite seams other than the A, B, G, H, and K are rarely more than a few inches thick (Jackson, 1968). In exposed parts of the Peridotite zone, the thicker chromite seams are easily found by detailed mapping. Between 1939 and 1942, the U.S. Geological Survey and the [U.S.] Bureau of Mines undertook a cooperative project in which the geology and resources of chromite in the complex were studied. All exposures of the Peridotite zone with significant concentrations of chromite were mapped and sampled (Peoples and Howland, 1940; Wimmler, 1948; Howland and others, 1949; Jackson and others, 1954; Peoples and others, 1954; Howland, 1955; Jones and others, 1960). Outcrop mapping at a scale of 1:1,200 was made for the most important prospect areas. Published locations of channel sample and trench sites are included in [still_bulk] and collar location of drill-holes are included in [still_sdh] (figs. 6 and 7). The information in these feature classes under-represent the amount of prospecting work that was done; almost all significant exposures of chromiteenriched rock in the complex were sampled.

\footnotetext{
${ }^{3}$ The seams are lettered A through $\mathrm{K}$, from the lowest to the highest in the stratigraphic section.
}

Historical mining focused on two chromite seams, the $\mathrm{G}$ (as much as $11.8 \mathrm{ft}$ thick) and the $\mathrm{H}$ (as much as $2.5 \mathrm{ft}$ thick) that occur in the middle of the Peridotite zone (fig. 1; Jackson, 1968). Ore averages 20 to 22 weight percent $\mathrm{Cr}_{2} \mathrm{O}_{3}$ from which concentrates were produced that average $\sim 38.5$ to 41.5 weight percent $\mathrm{Cr}_{2} \mathrm{O}_{3}$. The chromium- to- iron ratio is low, typically 1.44 to 1.61. Some development and mining was done along Little Rocky Creek (Benbow) and the Boulder River (Gish) preceding and during World War I. Mine development at Gish, Mouat-Sampson, and Benbow took place during the World War II. Underground development work at the Gish Mine, the Benbow Mine, and the Mouat-Sampson Mine during World War II allowed the chromite seams to be examined over a vertical extent of 492 to $984 \mathrm{ft}$ (Wimmler, 1948). Between 1952 and 1962, 2.1 million tons of ore yielding 920,000 tons of concentrate averaging 38.5 weight percent $\mathrm{Cr}_{2} \mathrm{O}_{3}$ were produced from the Mouat-Sampson Mine. Mining was done under contract to the U.S. government as part of a program to create stockpiles of materials critical for U.S. defense needs. The stockpile was sold in 1973.

Both the American Chrome Company (14 drill-holes in 1956 and 1957) and Chrome Corporation of America (14 drillholes in 1989) conducted underground exploration programs to extend the resources of the $\mathrm{G}$ and $\mathrm{H}$ chromite seams in the Mouat-Sampson Mine (Cooper, 1997). The G and H chromite seams were intersected in drill core at least $295 \mathrm{ft}$ below the number 5 level of the mine. Collar locations of these underground holes are not included in this compilation.

\section{PGE in Reef-Type Deposits}

\section{J-M Reef}

Howland and others (1936) recognized the potential for finding reef-type PGE mineralization in the Stillwater Complex. Thirty-seven years later (1973), the J-M Reef was discovered by Johns-Manville exploration geologists (figs. 1 and 3). Conn (1979) described exploration activities that led to the discovery of the J-M Reef. Unpublished geologic maps $(1: 1,200)$ show the outcrop geology all along the trace of the J-M Reef. Exploration activities also included soil geochemical surveys, ground-based geophysical surveys (most typically magnetics and induced-polarization), trenching, and drilling. The first mine on the J-M Reef, the Stillwater Mine, went into production in 1986, producing platinum and palladium as well as gold, rhodium, copper, and nickel. The second mine, the East Boulder, started production in 2001. The J-M Reef is represented in the [jm_reef] feature class included with this report.

The J-M Reef consists of 0.5 to 3 volume percent magmatic sulfide minerals that are associated with the 5 th olivine-bearing member of the Olivine-bearing I zone in the Lower Banded series. Sulfide and PGE mineralized rock typically extends over a 3.3- to 9.8-ft thick stratigraphic 
interval although mineralization is locally absent or may be more than $39 \mathrm{ft}$ thick. The strata that host the reef dip 50 to 60 degrees to the northwest of the West Fork of the Stillwater River; to the east, dips steepen and are locally overturned east of the Stillwater River.

Systematic geochemical surveys by Johns-Manville were instrumental in locating the J-M Reef (Zientek and others, 2005). Over 10,900 samples of soil, talus fines, seeps, and stream sediments were collected at 100 -ft intervals on contour traverses or lines in grid patterns. Grid sampling extends over the stratigraphic interval from below the contact between the Ultramafic series and the Lower Banded series to the Anorthosite I zone in the Middle Banded series. B-horizon soils were sampled where available, with the C-horizon serving as a second choice. For soil samples, about two heaping handfuls of material were collected. For talus samples, the finest material available in a $25-\mathrm{ft}$ radius around the site was taken. The samples were analyzed for platinum and palladium, with palladium being below the detection limit for fourteen percent of the locations $(1,498)$; and platinum being below the detection limit for almost half of the sites $(5,415)$. The locations of the sample sites are shown in the [still_Pd_Pt_soil] feature class. In these data, values below detection limits are indicated by negative values. The location of weak, moderate, and strong geochemically anomalous samples (for platinum and palladium) from these surveys is included in the feature class, [still_anom]. The anomalies categorized as "weak geochem anomaly" are where platinum plus palladium is $50-100 \mathrm{ppb}$, where platinum is less than palladium, and $80-200 \mathrm{ppb}$ where platinum is greater than palladium. Anomalies categorized as "moderate geochem anomaly" are where platinum plus palladium is $100-200 \mathrm{ppb}$ where platinum is less than palladium. The anomalies categorized as "strong geochem anomaly" are where platinum plus palladium is $>200 \mathrm{ppb}$.

Surface grids representing the geochemical data were generated from the [still_Pd_Pt_soil] feature class and are included with this report as [klpd] and [klpt] (fig. 8). Before the surface was created, censored values were replaced by a value of half the reported detection limit and the logarithms of the platinum and palladium values were calculated. Surfaces were calculated using the log-transformed values of palladium and platinum using the ordinary kriging method with a spherical semivariogram model. A variable search radius and 12 points were used. The surfaces were generated with the spatial analyst extension in Esri ArcGIS 8.3. The resulting surfaces were clipped by a polygon to limit the analysis to the areas that were sampled.

The [still_anom] dataset shows that the J-M Reef is readily located by tight linear clustering of anomalies that extend $328 \mathrm{ft}$ or more away from the reef. Clusters of anomalies below the reef correspond to lens-like or discordant PGE-enriched sulfide mineralization. Scattered anomalies above the reef show no consistent spatial pattern (clustering).

The location of surface drill-hole collars targeted at the J-M Reef by Anaconda, Manville, Stillwater PGM Resources, and Stillwater Mining Company are compiled in [still_sdh]. Holes not included in this compilation include

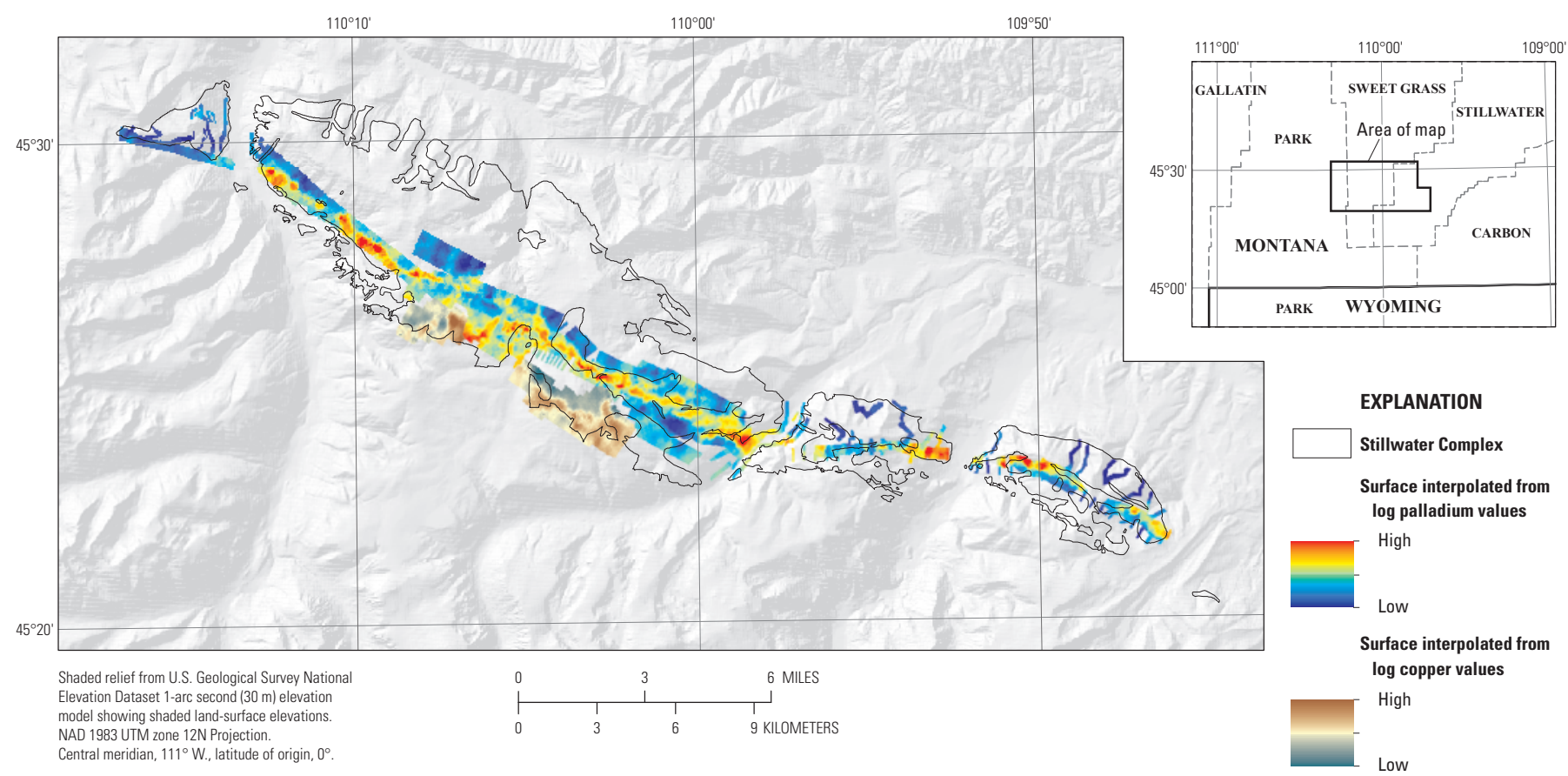

Figure 8. Map showing surface grids generated from palladium and copper soil geochemistry data in the Stillwater Complex. 
several holes drilled by Idaho Consolidated Metals near Black Butte and in the Iron Creek in 2001, as well as a deep hole collared in Paleozoic sedimentary rocks at Fishtail Creek that was drilled in the mid to late 1980s.

The locations of bulk sample sites on the J-M Reef are included in [still_bulk]. Numerous locations above the J-M Reef were sampled during the course of geologic mapping or geochemical sampling. No other PGE-enriched or laterally persistent sulfide mineralization has been reported for the interval between the base of the Anorthosite I zone and the J-M Reef.

\section{PGE-Enriched A and B Chromite Seams}

Stratiform chromite seams can be enriched in PGE to the extent that they can be considered for development strictly on their PGE content alone. The UG2 chromite seam in the Bushveld Complex represents one of the major repositories of PGE in the world (Sutphin and Page, 1986). Elevated PGE concentrations may be associated with sulfide minerals in the chromitites. However, the amount of sulfide minerals in these PGE-enriched chromitites is very low (much lower than 1 volume percent); sulfur content of the PGE-enriched chromite seams is typically $<100 \mathrm{ppm}$. Sulfide minerals are difficult to observe in the field; rarely, secondary copper minerals can be found on some mineralized chromitites.

In the Stillwater Complex, the highest PGE concentrations are consistently associated with the $\mathrm{A}$ and $\mathrm{B}$ chromite seams. The A and B chromite seams consist of one or more massive chromitite layers in a 4.9 to $14.8 \mathrm{ft}$ interval with disseminated chromite in olivine cumulate and thin chromitite layers in a cyclic unit near the base of the Peridotite zone. Exploration activity focused on these chromite seams in the eastern part of the Stillwater Complex.

Interest in the PGE concentrations of chromite-rich rocks postdates the wartime effort to evaluate the chromium resources in the complex. Exploration efforts are less comprehensive than the work to evaluate the chromium resources of the complex or the potential for reef-type mineralization in the Lower Banded series. Reconnaissance sampling reported by Page and others $(1969 ; 1972 ; 1976)$ obtained a suite of samples that stratigraphically represented all chromite seams in the Peridotite zone; the A chromite seam in the West Fork area was clearly anomalous because it had higher concentrations of palladium and platinum than other chromitite layers. Subsequent investigations subdivided the A chromite seam in the West Fork area (Mann and others, 1985). The lower chromite seam, the A, is finer-grained and laterally discontinuous; the upper group of chromite-enriched layers is coarser-grained, shows greater lateral continuity, and is referred to as the B chromite seam.

Based on the results summarized by Page and coworkers, several episodes of exploration activity focused on the PGE-enriched chromite seams in the West Fork - Crescent Creek area, first by Anaconda in 1969 and 1979, and later by
Boulder Gold in 1986 and 1987 (Reichl, 1991; 1992). The chromite seams in this area can be traced for $1.1 \mathrm{mi}$ on strike. Results of the work in 1979 identified 3.4 million metric tons of rock averaging $2.4 \mathrm{ppm}$ platinum and palladium over a nominal width of $3.9 \mathrm{ft}$. The best assays reported by Boulder Gold for this area are surface samples of the B chromite seam with $10.97 \mathrm{ppm}$ PGE over $3.6 \mathrm{ft}$ and $21.6 \mathrm{ppm}$ PGE over 6 inch (Boulder Gold, written comm., 1991). In the Mountain View area, Boulder Gold sampled the B chromite seam in outcrop and drilled three holes; in the Benbow area they sampled the A chromite seam in new trenches and drilled one hole. Trench and drill-hole locations for the work are included in [still_sdh] and [still_bulk].

\section{PGE in Other Deposit Types}

\section{Picket Pin Zone}

The Picket Pin zone is a disseminated sulfide mineralization concentrated against a grain-size contact near the top of the Anorthosite II zone in the Middle Banded series of the Stillwater Complex (fig 3; Boudreau and McCallum, 1986). The mineralization consists of 1 to 5 volume percent sulfide minerals that are associated with a pyroxene-free, quartz- and apatite-bearing interstitial mineral assemblage. Crudely stratabound mineralization is exposed for $13.7 \mathrm{mi}$ along strike and tends to be concentrated over a $32.8 \mathrm{ft}$ interval near the grain-size contact. However, scattered concentrations of sulfide minerals may be found as far as $492 \mathrm{ft}$ below this contact. Sulfide mineral accumulations in the cumulates have shapes that are like lenses (a few feet to about $100 \mathrm{ft}$ in extent) or pipes (3.3 to $6.6 \mathrm{ft}$ in diameter by $164 \mathrm{ft}$ long). The highest values determined for this mineralization were obtained from a surface sample that contained $7.9 \mathrm{ppm}$ palladium plus platinum (Boudreau, 1986).

Exploration activity focused on PGE-enriched sulfide mineralization that consistently occurs near the top of the Anorthosite II zone along its 13.7-mi strike-length. The Picket Pin zone was one of the first PGE-enriched sulfide occurrences recognized in the complex (Howland and others, 1936). Work on the Picket Pin mineralization included sampling mineralized outcrops, bulk sampling, and drilling. Systematic soil geochemical surveys have not been conducted; although ground magnetic surveys were used to locate the olivine-bearing rocks overlying the Anorthosite II zone in areas where these rocks are not exposed. Exploration activity summarized in [still_sdh] and [still_bulk] was done by Anaconda from 1979 to 1983 ; however, there was minimal information about the location of the holes and their orientation and the quality of this information is not as good as most of the other information in these feature classes. The location of 14 holes drilled by International Platinum and 3 holes drilled by the claim holders along the eastern 
part of the zone in the late 1980s are not included in this compilation.

\section{Pegmatoidal Lenses, Pipes, and Other Discordant Mineralization}

PGE-enriched magmatic sulfide minerals have been found in lens-like to discordant mafic pegmatoids in the upper part of the Bronzitite zone and the lower part of Lower Banded series of the Stillwater Complex. Many examples of sulfide-bearing mafic pegmatoids are recognized in the complex, but those that are PGE-enriched appear to be clustered in the area from Lost Mountain to north of Iron Mountain (fig. 6). Occurrences are commonly named for the mining claim on which they occur-Janet 50 ; Janet $55 \mathrm{~W}$, and Coors 602.

The geochemical surveys directed at locating reef-type mineralization in the Lower Banded series (see [still_anom]) located several anomalies in the Ultramafic series and Lower Banded series below the J-M Reef that turned out to be PGEenriched pegmatoidal lenses or discordant bodies. These areas were mapped, trenched, and drilled. The Janet 50 occurrence in the upper part of the Bronzitite zone extends over an area of 98 by $164 \mathrm{ft}$ and consists of a pegmatoidal bronzitite with disseminated sulfide minerals and local concentrations of graphite (Volborth and Housley, 1984). The average of 5 analyses of samples collected by the one of the authors (Zientek) from surface exposures of the Janet 50 pegmatoid gave the following results: 0.38 weight percent sulfur, 0.09 weight percent copper, 0.27 weight percent nickel, less than $2 \mathrm{ppb}$ iridium, $5 \mathrm{ppb}$ ruthenium, $16 \mathrm{ppb}$ rhodium, $692 \mathrm{ppb}$ platinum, $1,278 \mathrm{ppb}$ palladium, and $130 \mathrm{ppb}$ gold. Trenching, drilling, and mapping in the Coors 602 area has located several bronzite-rich pegmatoids in the Lower Banded series below the J-M Reef and a dike-like body of bronzitite that cuts the Lower Banded series (Mcllveen, 1996). An interval $25 \mathrm{ft}$ wide from one of the mineralized pegmatoids contained $4.4 \mathrm{ppm}$ platinum and $11 \mathrm{ppm}$ palladium (Conn, 1979). The Janet 55W zone consists of disseminated sulfide mineralization associated with bronzite-rich pegmatoids immediately below the J-M Reef. An interval $4.6 \mathrm{ft}$ wide contained $7.2 \mathrm{ppm}$ palladium plus platinum. Although many of the pegmatoids in the Coors 602 area contain sulfide minerals, not all are enriched in PGE.

\section{Other Styles of Mineralization}

Concentrations of chromite and sulfide minerals also have been found along the contact between an alaskite intrusion and the Stillwater Complex that crops out south of Picket Pin Mountain (fig. 6; Czamanske and others, 1991). These rocks are enriched in PGE and were one of the first occurrences studied by Johns-Manville in 1968 (Conn, 1979). A bulk sample from this occurrence assayed $5.1 \mathrm{ppm}$ platinum, $3.4 \mathrm{ppm}$ palladium, $0.4 \mathrm{ppm}$ rhodium, 0.24 percent nickel, 0.03 percent copper, and 5 percent chromium (Conn, 1979).

\section{Description of Feature Classes in Stillwater_Complex.gdb-Exploration Datasets}

\section{Mine Tunnels, Shafts, Adits, and Portals, Stillwater Complex, Montana (still_mines)}

The [still_mines] point feature class provides spatial and descriptive data for mine tunnels, shafts, adits, and portals in the Stillwater Complex. The data show locations of underground PGE, chrome, and copper-nickel exploration and mining.

This dataset was created by digitizing points on-screen using a geographic information system (GIS). Locations were sourced from georeferenced maps or photo imagery of the Stillwater Complex. The shapefile was then converted to a geodatabase feature class. Data sources are listed in the Ref_short field, and full references are listed in the "References Cited" section of this report. The attribute table fields and their definitions are listed in table 10. This dataset is not meant to be displayed at larger than 1:12,000.

\section{Copper and Nickel Soil Geochemistry, Stillwater Complex, Montana (amax_soil_gchm)}

The [amax_soil_gchm] point feature class provides spatial and descriptive data for copper and nickel geochemistry data from soil samples collected by AMAX Inc. in the Stillwater Complex. The data may indicate the presence of nickel and copper sulfide minerals in underlying strata. Gridding the data provides a mechanism to examine patterns for anomalous metal values.

This dataset was created by scanning and georeferencing unpublished paper maps from AMAX Inc., and digitizing points on-screen using a GIS. A data structure was designed and the copper and nickel values were transferred from the maps into the attribute table. The attribute table fields and their definitions are listed in table 11. The file was reprojected to UTM Zone 12N NAD 1983 and converted to a geodatabase feature class. This dataset is not meant to be displayed at larger than 1:12,000.

Table 10. Description of attribute table fields for the [still_mines] feature class.

\begin{tabular}{ll}
\hline \multicolumn{1}{c}{ Field name } & \multicolumn{1}{c}{ Field description } \\
\hline Name & Name of feature. \\
Commodity & Commodity being mined. \\
Mine_name & Name of mine. \\
Feature & Type of feature. \\
Ref_short & $\begin{array}{l}\text { Abbreviated reference for source document; } \\
\text { full references are listed in the "Refer- } \\
\text { ences Cited" section of this report. }\end{array}$ \\
\hline
\end{tabular}


Table 11. Description of attribute table fields for the [amax_soil_ gchm] feature class.

\begin{tabular}{ll}
\hline \multicolumn{1}{c}{ Field name } & \multicolumn{1}{c}{ Field description } \\
\hline CU_PPM & $\begin{array}{c}\text { Concentration of copper, in parts per mil- } \\
\text { lion. }\end{array}$ \\
NI_PPM & Concentration of nickel, in parts per million. \\
NORTHING & $\begin{array}{l}\text { Y coordinates given in Montana State Plane } \\
\text { South feet, North American Datum of } \\
\text { 1927 (NAD27). }\end{array}$ \\
EASTING & $\begin{array}{l}\text { X coordinates given in Montana State Plane } \\
\text { South feet, North American Datum of } \\
\text { 1927 (NAD27). }\end{array}$ \\
DENOM & $\begin{array}{l}\text { Map-scale denominator for the original base } \\
\text { map used for a location map. }\end{array}$ \\
WORK_BY_ID & $\begin{array}{l}\text { Name of company primarily responsible } \\
\text { for conducting the work (collecting soil } \\
\text { samples). }\end{array}$ \\
\hline LAT & Latitude, in decimal degrees, GCS North \\
American Datum 1983.
\end{tabular}

\section{Platinum and Palladium Soil Samples, Stillwater Complex, Montana (still_Pd_Pt_soil)}

The [still_Pd_Pt_soil] point feature class provides spatial and descriptive data for platinum and palladium geochemistry data from soil samples collected by Stillwater PGM Resources geologists in the Stillwater Complex. The data may indicate the presence of platinum and palladium minerals in underlying strata.

The feature class was constructed from 1:4,800-scale paper maps provided by Stillwater PGM Resources in the early 1990s. Paper maps were georeferenced and points were digitized on screen using a GIS. The attribute table fields and their definitions are listed in table 12. The shapefile was converted to a geodatabase feature class and reprojected to UTM Zone 12 NAD 1983. This dataset is not meant to be displayed at larger than 1:4,800.

\section{Platinum and Palladium Soil Sample Anomalies, Stillwater Complex, Montana (still_anom)}

The [still_anom] point feature class provides spatial and descriptive data for platinum and palladium anomalies from soil samples collected by the Johns-Manville Corporation in 1975, in the Stillwater Complex. The data may indicate the

Table 12. Description of attribute table fields for the [still_Pd_Pt_soil] feature class.

Field name

PD_PPB

\section{Field description}

Palladium concentration, in parts per billion. Negative numbers indicate analyses that are below the limit of detection.

PD_PPB_SUB Palladium concentration, in parts per billion. Censored values are replaced by half the reported detection limit.

LOG_PD_SUB Logarithm of palladium concentration with replaced censored values.

PT_PPB Platinum concentration, in parts per billion. Negative numbers indicate analyses that are below the limit of detection.

PT_PPB_SUB Platinum concentration, in parts per billion. Censored values are replaced by half the reported detection limit.

LOG_PT_SUB Logarithm of platinum concentration with replaced censored values.

DENOM Map-scale denominator for the original base map used for a location map.

WORK_BY_ID N Name of company primarily responsible for conducting the work (collecting soil samples).

EASTING X coordinates given in Montana State Plane South feet, North American Datum of 1927 (NAD27).

NORTHING Y coordinates given in Montana State Plane South feet, North American Datum of 1927 (NAD27).

LON Longitude, in decimal degrees, GCS North American Datum 1983. 
presence of platinum and palladium minerals in underlying strata.

This dataset was created by scanning and georeferencing 12 unpublished paper maps from the Johns-Manville Corporation and digitizing points using GSMAP (Selner and Taylor, 1992). The USGS program GSMGIS.exe version 9 was used to make two ASCII files. The ASCII files were converted to a shapefile, and reprojected to Montana State Plane South. All points were checked against georeferenced images for location and proper attribution. A rudimentary database structure was created and populated. The attribute table fields and their definitions are listed in table 13 . The shapefile was converted to a geodatabase feature class and reprojected to UTM Zone 12 NAD 1983. This dataset is not meant to be displayed at larger than $1: 12,000$.

\section{Trench and Bulk Sample Locations, Stillwater Complex, Montana (still_bulk)}

The [still_bulk] point feature class provides spatial and descriptive data for trenches and bulk geochemical sample sites in the Stillwater Complex (fig. 6). Twenty-five published and unpublished paper maps, including those from Anaconda, Johns-Manville Corporation, Stillwater PGM Resources, and the U.S. Geological Survey, were used to create this file. Detailed source information is listed in the metadata. The point features show locations of trenches and sites that were analyzed for chromite, copper-nickel, and PGE mineralization.

This dataset was created by scanning and georeferencing paper maps and digitizing points using GSMAP (Selner and Taylor, 1992). A center point was used for trench locations that were plotted as linear features. The USGS program GSMGIS.exe version 9 was used to make two ASCII files. The ASCII files were converted to a shapefile, and reprojected to Montana State Plane South. All points were checked against georeferenced images for location and proper attribution. A

Table 13. Description of attribute table fields for the [still_anom] feature class.

\begin{tabular}{|c|c|}
\hline Field name & Field description \\
\hline ANOM_CLASS & $\begin{array}{l}\text { Classification of platinum and palladium } \\
\text { soil geochemical anomalies. }\end{array}$ \\
\hline NORTHING & $\begin{array}{l}\text { Y coordinates given in Montana State Plane } \\
\text { South feet, North American Datum of } \\
1927 \text { (NAD27). }\end{array}$ \\
\hline EASTING & $\begin{array}{l}\text { X coordinates given in Montana State Plane } \\
\text { South feet, North American Datum of } \\
1927 \text { (NAD27). }\end{array}$ \\
\hline LAT & $\begin{array}{l}\text { Latitude, in decimal degrees, GCS North } \\
\text { American Datum } 1983 .\end{array}$ \\
\hline LONG & $\begin{array}{l}\text { Longitude, in decimal degrees, GCS North } \\
\text { American Datum } 1983 .\end{array}$ \\
\hline DENOM & $\begin{array}{l}\text { Map scale denominator of map used to } \\
\text { locate and verify sample site. }\end{array}$ \\
\hline
\end{tabular}

rudimentary database structure was created and populated. The attribute table fields and their definitions are listed in table 14 . The shapefile was converted to a geodatabase feature class and reprojected to UTM Zone 12 NAD 1983. This dataset is not meant to be displayed at larger than 1:62,500.

\section{Drill-Holes, Stillwater Complex, Montana (still_ sdh)}

The [still_sdh] point feature class provides spatial and descriptive data for surface drill-holes in the Stillwater Complex (fig. 7). Drill-hole data from private companies, government agencies, and private individuals were used in the creation of the file. Source material includes unpublished mining company maps, U.S. Geological Survey scientist's field map sheets, published maps, and published sample site location coordinates. Exploration and mining companies and exploration geologists provided most of the information used to create this feature class. Of the 1,089 records, 54 locations were derived from published sources; 990 of the records were derived from documents provided by Anaconda, Johns-Manville Corporation, Stillwater PGM Resources, and Cyprus. Approximately 12 unpublished reports document work conducted by Anaconda from the 1930s to the early 1980s. Johns-Manville Corporation provided access to unpublished reports that documented exploration activities conducted by AMAX Inc. from 1969 to 1977. Cyprus provided information about their drilling program conducted from 1971 to 1980 . Stillwater PGM Resources provided 1:4,800-scale generalized geologic maps and tabular data that document exploration drilling on the J-M Reef from

Table 14. Description of attribute table fields for the [still_bulk] feature class.

\begin{tabular}{ll}
\hline \multicolumn{1}{c}{ Field name } & \multicolumn{1}{c}{ Field description } \\
\hline TRENCH_ID & Trench or pit site identifier. \\
TARGET & $\begin{array}{c}\text { The feature (target) that was tested by drill- } \\
\text { ing or trenching. }\end{array}$ \\
TARGET_COM & $\begin{array}{c}\text { Commodities characteristic of mineral de- } \\
\text { posit type if target is mineralized rock. }\end{array}$ \\
NORTHING & $\begin{array}{c}\text { Y coordinates given in Montana State Plane } \\
\text { South feet, North American Datum of } \\
\text { 1927 (NAD27). }\end{array}$ \\
EASTING & $\begin{array}{c}\text { X coordinates given in Montana State Plane } \\
\text { South feet, North American Datum of } \\
\text { 1927 (NAD27). }\end{array}$ \\
LAT & $\begin{array}{c}\text { Latitude, in decimal degrees, GCS North } \\
\text { American Datum 1983. }\end{array}$ \\
LONG & $\begin{array}{l}\text { Longitude, in decimal degrees, GCS North } \\
\text { American Datum 1983. }\end{array}$ \\
DENOM & $\begin{array}{l}\text { Map scale denominator of map used to } \\
\text { locate and verify sample site. }\end{array}$ \\
\hline
\end{tabular}


1969 to 1993 . Additional detailed source information is listed in the metadata. The point features show locations of drillholes that were analyzed for chromite, copper, nickel, PGE, and gold mineralization. Drill-hole depths range from $<2$ to $2,806 \mathrm{ft}$.

This dataset was created by scanning and georeferencing paper maps and digitizing points using GSMAP (Selner and Taylor, 1992). The USGS program GSMGIS.exe version 9 was used to make two ASCII files. The ASCII files were converted to a shapefile, and reprojected to Montana State Plane South. All points were checked against georeferenced images for location and proper attribution. A rudimentary database structure was created and populated. The attribute table fields and their definitions are listed in table 15 . The shapefile was converted to a geodatabase feature class and reprojected to UTM Zone 12 NAD 1983. This dataset is not meant to be displayed at larger than $1: 62,500$.

\section{Nickel-Copper Assay Data from Contact-Type Sulfide Exploration Projects (CuNi_assay.xlsx)}

Exploration companies analyzed over 24,000 samples of drill core for copper and nickel when they were evaluating the sulfide deposits near the base of the Stillwater Complex. This work started in 1966 and was largely finished by 1983 . Analytical methods used to determine the copper and nickel values are not known. For most of the analyses, the nickel values reflect the total nickel content of the rock. For some material, nickel was determined on a selective leach that would indicate the amount of nickel in sulfide minerals in the rock. This was important for rocks that contained both sulfide minerals and olivine. Standard beneficiation (crushing and separating ore into valuable substances or waste by any of a variety of techniques) processes could recover nickel in the sulfide minerals; nickel in olivine could not be recovered.

These analytical data were provided to the USGS. Information from paper copies of assay reports and data sheets were transferred to a digital format. Most of the information was hand-written and some was difficult to read because of poor quality reproductions. Data provided by each company were in a slightly different format. Information was entered as shown on the reports and then reformatted so that the data could be merged into a single file. Hole names were reformatted to correspond to names used in the feature class [still_sdh]. Copper and nickel values originally reported as "less than" are shown as negative numbers. In the process of merging the data, check assays or analyses of internal standards that were in some reports were excluded. Data entry was checked by looking for obvious errors including (1) were the values for copper and nickel reasonable, (2) were footages listed as the beginning of the assay interval (from) less than the footage at the end of the assay interval (to), and (3) were reported recoveries less than or equal to 100 percent. This information is presented as an Excel spreadsheet, [CuNi_assay.xlsx], and a tab-delimited text file, [CuNi_assay.txt]. The column headings in the [CuNi_assay. xlsx] spreadsheet are defined in table 16.

Each company employed a slightly different sampling strategy; these differences will affect how the user interprets the data. Anaconda used a rock bit at the start of the hole and continued until they encountered rock competent enough to obtain core. Samples of the sludge from the rock bit intervals were collected and submitted for analysis; recoveries for the rock bit intervals are listed as "- 1 " in the "rec_core" column of the

Table 15. Description of attribute table fields for the [still_sdh] feature class.

\begin{tabular}{|c|c|}
\hline Field name & Field description \\
\hline DDH_ID & Diamond drill-hole identifier. \\
\hline TARGET & The feature (target) that was tested by drilling or trenching. \\
\hline TARGET_COM & Commodities characteristic of mineral deposit type if target is mineralized rock. \\
\hline WORK_BY_ID & $\begin{array}{l}\text { Name of company or government agency that was primarily responsible for conducting the work (collecting samples } \\
\text { from outcrops or trenches or drilling core). }\end{array}$ \\
\hline EASTING & X coordinates given in Montana State Plane South feet, North American Datum of 1927 (NAD27). \\
\hline DENOM & Map-scale denominator for the original base map used for a location map. \\
\hline AZIMUTH & $\begin{array}{l}\text { Bearing of inclined drill-hole measured in degrees using a 360-degree circle in a clockwise direction starting at due } \\
\text { North (no value indicates vertical hole). }\end{array}$ \\
\hline YEAR_DRILL & Year in which the drill-hole was completed. \\
\hline LAT & Latitude, in decimal degrees, GCS North American Datum 1983. \\
\hline LONG & Longitude, in decimal degrees, GCS North American Datum 1983. \\
\hline
\end{tabular}


compilation. Core was split lengthwise by sawing and all core collected was assayed. Core was combined into assay intervals that were no smaller than $1 \mathrm{ft}$ and did not exceed $10 \mathrm{ft}$. Assay intervals were varied to reflect lithologic changes observed in the core. Cyprus did not sample and analyze rock bit sludge. Core was split lengthwise and all core was assayed. Core was combined using $10-\mathrm{ft}$ intervals and assay intervals were not adjusted to reflect rock type. One hole had a composite interval of $5 \mathrm{ft}$. AMAX Inc. did not sample and analyze rock bit sludge. For mineralized rock, core was split lengthwise with a hydraulic knife. Core was then combined into assay intervals that were generally $<10 \mathrm{ft}$. Assay intervals were adjusted to reflect lithologic breaks. For intervals of unmineralized rock adjacent to mineralized intervals, chip samples of core were selected throughout a large interval (as much as $50 \mathrm{ft}$ ) and combined for analysis. Lindgren did not sample and analyze rock bit sludge. Only mineralized rock was selected for analysis and core was combined into assay intervals that were as much as $5 \mathrm{ft}$ long.

\section{Exploration Trenches, Stillwater Complex, Montana (still_trenches)}

The [still_trenches] line feature class represents exploration trenches in the Stillwater Complex. This dataset was created by digitizing the features shown on georeferenced air photos using a GIS. The attribute table fields contained within this feature class their descriptions are listed in table 17. This dataset is not meant to be displayed at larger than 1:12,000.

\section{J-M Reef, Stillwater Complex, Montana (jm_ reef)}

The [jm_reef] line feature class represents the surface trace of the J-M Reef of the Stillwater Complex (figs. 1 and 3). This dataset was created by digitizing the features shown on 11 unpublished 1:4,800-scale geologic maps (Stillwater PGM Resources, written commun., 1982-85). The geologic maps were scanned and georeferenced and the features were digitized on-screen using a GIS. The user defined field contained within this feature class is listed in table 3 , and the field description is listed in table 6 . This dataset is not meant to be displayed at larger than $1: 4,800$.

\section{References Cited}

American Geosciences Institute, 2014, Glossary of geology: American Geosciences Institute Web page, accessed March 10, 2014, at http://glossary.agiweb.org/dbtw-wpd/glossary/ search.aspx.

Blakely, R.J., 1984, Map showing aeromagnetic data over the Stillwater Complex and vicinity, Montana: U.S. Geological Survey Open-File Report 84-799, 3 sheets, scale 1:24,000.
Table 16. Definitions for column headings in the [CuNi_assay. xlsx] spreadsheet.

\begin{tabular}{ll}
\hline \multicolumn{1}{c}{ Column heading } & \multicolumn{1}{c}{ Column heading definition } \\
\hline ddh_id & $\begin{array}{l}\text { Diamond drill-hole identifier. } \\
\text { work_by_id }\end{array}$ \\
locality & $\begin{array}{l}\text { Name of the company that drilled the hole. } \\
\text { Nag_number }\end{array}$ \\
Name of the area where the hole was drilled. \\
from
\end{tabular}

Table 17. Description of attribute table fields for the [still_ trenches] feature class.

\begin{tabular}{lc}
\hline \multicolumn{1}{c}{ Field name } & \multicolumn{1}{c}{ Field description } \\
\hline TARGET & The feature (target) that was tested. \\
& $\begin{array}{c}\text { Commodities characteristic of mineral de- } \\
\text { posit type if target is mineralized rock. } \\
\text { NA, not applicable. }\end{array}$ \\
\hline
\end{tabular}


Boudreau, A.E., 1986, The role of fluids in the petrogenesis of platinum-group element deposits in the Stillwater Complex, Montana: Seattle, University of Washington, Ph.D. dissertation, $247 \mathrm{p}$.

Boudreau, A.E., and McCallum, I.S., 1986, Investigations of the Stillwater Complex; III. The Picket Pin Pt/Pd deposit: Economic Geology, v. 81, p. 1953-1975.

Conn, H.K., 1979, The Johns-Manville platinum-palladium prospect, Stillwater Complex, Montana, U.S.A.: Canadian Mineralogist, v. 17, p. 463-468.

Cooper, R.W., 1997, Magmatic unconformities and stratigraphic relations in the Peridotite zone, Stillwater Complex, Montana: Canadian Journal of Earth Sciences, v. 34, p. 407-425.

Czamanske, G.K., Zientek, M.L., and Manning, C.E., 1991, Low-K granophyres of the Stillwater Complex, Montana: American Mineralogist, v. 76, p. 1646-1661.

Foose, M.P., 1985, Geologic map of part of the East Boulder Plateau-Contact Mountain area, in Czamanske, G.K., and Zientek, M.L., eds., The Stillwater Complex, MontanaGeology and guide: Montana Bureau of Mines and Geology Special Publication 92, sheet 4 of 4, scale 1:6,000.

Hammarstrom, J.M., Elliott, J.E., Van Gosen, B.S., and Zientek, M.L., 1993, The Absaroka-Beartooth study area, in Hammarstrom, J.M., Zientek, M.L., and Elliott, J.E., eds., Mineral resource assessment of the Absaroka-Beartooth study area, Custer and Gallatin National Forests, Montana: U.S. Geological Survey Open-File Report 93-207, p. A1A22.

Hess, H.H., 1960, Stillwater igneous complex, MontanaA quantitative mineralogical study, with an appendix on Optical properties of low-temperature plagioclase, by J.R. Smith: Geological Society of America Memoir 80, 230 p.

Howland, A.L., 1955, Chromite deposits in central part Stillwater Complex, Sweet Grass County, Montana: U.S. Geological Survey Bulletin 1015-D, p. 99-121.

Howland, A.L., Garrels, E.M., and Jones, W.R., 1949, Chromite deposits of Boulder River area, Sweetgrass County, Montana: U.S. Geological Survey Bulletin 948-C, p. 63-82.

Howland, A.L., Peoples, J.W., and Sampson, E., 1936, The Stillwater Igneous Complex and associated occurrences of nickel and platinum metals: Montana Bureau of Mines and Geology Miscellaneous Contribution 7, 15 p.

Hunter, R.H., 1987, Textural equilibrium in layered igneous rocks, in Parson, Ian, ed., Origins of igneous layering: D. Reidel Publishing Company, NATO ASI Series, Series CMathematical and Physical Sciences, v. 196, p. 473-503.
Intermap, 2012, NEXTMap digital terrain model: Intermap Web page, at https://www.intermap.com.

Irvine, T.N., 1982, Terminology for layered intrusions: Journal of Petrology, v. 23, p. 127-162.

Jackson, E.D., 1961, Primary textures and mineral associations in the Ultramafic zone of the Stillwater Complex, Montana: U.S. Geological Survey Professional Paper 358, 106 p.

Jackson, E.D., 1967, Ultramafic cumulates in the Stillwater, Great Dyke, and Bushveld intrusions, in Wyllie, P.J., ed., Ultramafic and related rocks: New York, Wiley, p. 20.

Jackson, E.D., 1968, The chromite deposits of the Stillwater Complex, Montana, in Ridge, J.D., ed., Ore deposits of the United States, 1933-1967 (Graton-Sales volume): N.Y,, American Institute of Mining, Metallurgical and Petroleum Engineers, v. 2, p. 1495-1510.

Jackson, E.D., Howland, A.L., Peoples, J.W., and Jones, W.R., 1954, Geologic maps and sections of the eastern part of the Stillwater Complex in Stillwater County, Montana: U.S. Geological Survey Open-File Report 54-133, 4 sheets, scale $1: 2,400$.

Jones, W.R., Peoples, J.W., and Howland, A.L., 1960, Igneous and tectonic structures of the Stillwater Complex, Montana: U.S. Geological Survey Bulletin 1071-H, p. 281-340.

LeRoy, L.W., 1985, Troctolite-Anorthosite zone I and the J-M Reef-Frog Pond adit to the Graham Creek area, in Czamanske, G.K., and Zientek, M.L., eds., The Stillwater Complex, Montana - Geology and guide: Montana Bureau of Mines and Geology Special Publication 92, p. 325-333.

Mann, E.L. (Bob), Lipin, B.R., Page, N.J, Foose, M.P., and Loferski, P.J., 1985, Guide to the Stillwater Complex exposed in the West Fork area, in Czamanske, G.K., and Zientek, M.L., eds., The Stillwater Complex, MontanaGeology and guide: Montana Bureau of Mines and Geology Special Publication 92, p. 231-246.

McCallum, I.S., Raedeke, L.D., and Mathez, E.A., 1980, Investigations of the Stillwater Complex; Part I. Stratigraphy and structure of the Banded zone: American Journal of Science, v. 280-A, no. 1, p. 59-87.

McIlveen, C.L., 1996, An anomalous platinum-group element occurrence below the JM Reef, Stillwater Complex, Montana: Missoula, University of Montana, M.S. thesis, 74 p.

Page, N.J, 1979, Stillwater Complex, Montana-Structure, mineralogy, and petrology of the Basal zone with emphasis on the occurrence of sulfides: U.S. Geological Survey Professional Paper 1038, 69 p. 
Page, N.J, and Nokleberg, W.J., 1974, Geologic map of the Stillwater Complex, Montana: U.S. Geological Survey Miscellaneous Investigation Series Map I-797, 5 sheets, scale 1:12,000.

Page, N.J., Nokleberg, W.J., and Miller, R.J., 2002, Geologic map of the Stillwater Complex, Montana-A digital database: U.S. Geological Survey Miscellaneous Investigation Series Map I-797, version 1.0, 29 p., 5 digital plates, scale $1: 12,000$.

Page, N.J, Riley, L.B., and Haffty, J., 1969, Platinum, palladium, and rhodium analyses of ultramafic and mafic rocks from the Stillwater Complex, Montana: U.S. Geological Survey Circular 624, 12 p.

Page, N.J, Riley, L.B., and Haffty, Joseph, 1972, Vertical and lateral variation of platinum, palladium, and rhodium in the Stillwater Complex, Montana: Economic Geology, v. 67, p. 915-923.

Page, N.J, Rowe, J.J., and Haffty, J., 1976, Platinum metals in the Stillwater Complex, Montana: Economic Geology, v. 71, p. 1352-1363.

Page, N.J, Zientek, M.L., Lipin, B.R., Mann, E.L., Schmidt, E.A., Turner, A.R., Czamanske, G.K., and Raedeke, L.D., 1985, Exploration and mining history of the Stillwater Complex and adjacent rocks, in Czamanske, G.K., and Zientek, M.L., eds., The Stillwater Complex, MontanaGeology and guide: Montana Bureau of Mines and Geology Special Publication 92, p. 77-92.

Peoples, J.W., and Howland, A.L., 1940, Chromite deposits of the eastern part of the Stillwater Complex, Stillwater County, Montana: U.S. Geological Survey Bulletin 922-N, p. $371-416$.

Peoples, J.W., Howland, A.L., Jones, W.R., and Flint, D., 1954, Geologic map, sections, and map of underground workings of the Mountain View Lake area, Stillwater County, Montana: U.S. Geological Survey Open-File Report 54-238, 11 sheets, scale 1:1,200.

Peterson, J.A., Zientek, M.L., and Cooper, R.W., 1995, Stratigraphic columns for traverses through the lower and middle Banded series, Stillwater Complex, Stillwater County, Montana: U.S. Geological Survey Miscellaneous Field Studies Map 2274, 2 sheets.

Premo, W.R., Helz, R.T., Zientek, M.L., and Langston, R.B., 1990, U-Pb and Sm-Nd ages for the Stillwater Complex and its associated sills and dikes, Beartooth Mountains, Montana-Identification of a parent magma?: Geology, v. 18, no. 11, p. $1065-1068$.

Raedeke, L.D., 1982, Petrogenesis of the Stillwater Complex: Seattle, University of Washington, Ph.D. dissertation, 212 p.
Raedeke, L.D., and McCallum, I.S., 1982, Modal and chemical variations in the Ultramafic zone of the Stillwater Complex, in Walker, D., and McCallum, I.S., eds., Workshop on magmatic processes of early planetary crusts - Magma oceans and stratiform layered intrusions: Houston, Texas, Lunar and Planetary Institute Technical Report 82-01, p. 135-137.

Raedeke, L.D., and McCallum, I.S., 1984, Investigations in the Stillwater Complex-Part II. Petrology and petrogenesis of the Ultramafic series: Journal of Petrology, v. 25, p. 395-420.

Reichl, Pavel, 1991, Petrology and geochemistry of the Peridotite zone in the West Fork area, Stillwater Complex, Montana: Missoula, University of Montana, Ph.D. dissertation, $170 \mathrm{p}$.

Reichl, Pavel, 1992, Petrogenesis and PGE mineralization of the Peridotite zone, West Fork area, Stillwater Complex, Montana, in Elliott, J.E., ed., Guidebook for the Red LodgeBeartooth Mountains-Stillwater area: Northwest Geology, v. 20-21, p. 97-115.

Roby, R.N., 1949, Investigation of copper-nickel deposits of the Stillwater Complex, Stillwater and Sweetgrass Counties, Montana: [U.S.] Bureau of Mines Report of Investigations 4431, 10 p.

Schulte, R.F., Taylor, R.D., Piatak, N.M., and Seal, R.R., II, 2012, Stratiform chromite deposit model, chap. E of Mineral deposit models for resource assessment: U.S. Geological Survey Scientific Investigations Report 2010-5070-E, $131 \mathrm{p}$.

Segerstrom, Kenneth, and Carlson, R.R., 1982, Geologic map of the Banded upper zone of the Stillwater Complex and adjacent rocks, Stillwater, Sweet Grass, and Park Counties, Montana: U.S. Geological Survey Miscellaneous Investigation Series Map I-1383, two sheets, scale 1:24,000.

Selner, G.I., and Taylor, B.T., 1992, System 8-GSMAP, GSMEDIT, GSMUTIL, GSPOST, GSDIG and other programs (version 8) for the IBM PC and compatible microcomputers, to assist workers in the earth sciences: U.S. Geological Survey Open-File Report 92-217, 217 p.

Stillwater PGM Resources, 1985, Geology of Troctolite Anorthosite Zone I exposed from the Frog Pond area to the headwaters of Blakely Creek, Stillwater Complex, Montana, in Czamanske, G.K., and Zientek, M.L., eds., The Stillwater Complex, Montana - Geology and guide: Montana Bureau of Mines and Geology Special Publication 92, sheet 3 of 4, scale 1:6,000.

Streckeisen, A.L., 1973, Plutonic rocks-Classification and nomenclature recommended by the IUGS Subcommission and the systematics of igneous rocks: Geotimes, v. 18, no. 10, p. 26-30. 
Sutphin, D.M., and Page, N.J, 1986, International strategic minerals inventory summary report-Platinum-group metals: U.S. Geological Survey Circular 930-E, 34 p.

Todd, S.G., Keith, D.W., LeRoy, L.W., Schissel, D.J., Mann, E.L., and Irvine, T.N., 1982, The JM platinum-palladium reef of the Stillwater Complex, Montana; I. Stratigraphy and petrology: Economic Geology, v. 77, no. 6, p. 1454-1480.

Volborth, A., and Housley, R.M., 1984, A preliminary description of complex graphite, sulphide, arsenide, and platinum group element mineralization in a pegmatoid pyroxenite of the Stillwater Complex, Montana, U.S.A.: Tschermaks Mineralogische und Petrographische Mitteilungen, v. 33, p. 213-230.

Wager, L.R., Brown, G.M., and Wadsworth, W.J., 1960, Types of igneous cumulates: Journal of Petrology, v. 1, p. 73-85.

Wimmler, N.L., 1948, Investigation of chromite deposits of the Stillwater Complex, Stillwater and Sweetgrass Counties, Montana: [U.S.] Bureau of Mines Report of Investigations 4368, $41 \mathrm{p}$.

Zientek, M.L., 1983, Petrogenesis of the Basal zone of the Stillwater Complex, Montana: Stanford, Calif., Stanford University, Ph.D. dissertation, 246 p.

Zientek, M.L., 1993, Mineral resource appraisal for locatable mineral-The Stillwater Complex, in Hammarstrom, J.M., Zientek, M.L., and Elliott, J.E., eds., Mineral resource assessment of the Absaroka-Beartooth study area, Custer and Gallatin National Forests, Montana: U.S. Geological Survey Open-File Report 93-207, p. F1-F83.

Zientek, M.L., 2012, Magmatic ore deposits in layered intrusions-Descriptive model for reef-type PGE and contacttype Cu-Ni-PGE deposits: U.S. Geological Survey, OpenFile Report 2012-1010, 48 p.

Zientek, M.L., Bawiec, W.J., Page, N.J, and Cooper, R.W., 1989, Maps, sections, and structure-contour perspective diagrams showing the geology and geochemistry of the Mouat nickel-copper prospect, Stillwater Complex, Stillwater County, Montana: U.S. Geological Survey Miscellaneous Field Studies Map MF-2038, 2 sheets, 1:2,400 scale.

Zientek, M.L., Carver, M.S., and Mooney, T.C., 1993, Geologic map, Stillwater Complex, Montana, in Hammarstrom, J.M., Zientek, M.L., and Elliott, J.E., eds., Mineral resource assessment of the Absaroka-Beartooth study area, Custer and Gallatin National Forests, Montana: U.S. Geological Survey Open-File Report 93-207, plate 14 of 19, scale $1: 126,720$.
Zientek, M.L., Cooper, R.W., Corson, S.R., and Geraghty, E.P., 2002, Platinum-group element mineralization in the Stillwater Complex, Montana, in Cabri, L.J., ed., The geology, geochemistry, mineralogy and mineral beneficiation of platinum-group elements: Canadian Institute of Mining and Metallurgy Special Volume 54, p. 459-481.

Zientek, M.L., Corson, S.R., and West, R.D., 2005, Geochemical surveys of soil and talus fines and the discovery of the J-M Reef, Stillwater Complex, Montana, chap. 18 of Mungall, J.E., ed., Exploration for platinum-group element deposits: Ottawa, Mineralogical Association of Canada Short Course Series, v. 35, p. 391-407.

Zientek, M.L., Czamanske, G.K., and Irvine, T.N., 1985, Stratigraphy and nomenclature for the Stillwater Complex, in Czamanske, G.K., and Zientek, M.L., eds., The Stillwater Complex, Montana-Geology and guide: Montana Bureau of Mines and Geology Special Publication 92, p. 21-32.

\section{Appendix A-Lithologic Terminology Used for the Stillwater Complex}

Distinctive textural and compositional features characterize igneous rocks that make up the Stillwater Complex. These rocks consist of high temperature minerals that crystallize from mafic silicate melts, but in proportions that are not appropriate for the bulk composition of naturally occurring mafic magma. The rocks (cumulates) are depleted in (1) minerals that crystallize late and (2) elements that behave incompatibly during crystallization of silicate magma. Finally, the rocks commonly show igneous layering. Igneous layers are defined by variations in mineralogy, texture, mineral proportions, and grain size as the result of the crystallization of mafic magmas.

The evolution of geologic thought on how these rocks form is reflected in the variety of rock names that have been used to describe the Stillwater Complex (table A1). Igneous rocks associated with the Stillwater Complex have been described using (1) names that reflect the total mode of all minerals in the rock (Jackson, 1967); (2) cumulate nomenclature as described by Wager and others (1960, p. 85), Jackson (1961, 1967), Irvine (1982), and Zientek and others (1985); and (3) "traditional" rock names that are based on the mode of cumulus minerals (Raedeke, 1982; Todd and others, 1982; Irvine, 1982); and (4) names that reflect the chemical compositional characteristics of the rocks (Helz, 1985). Each approach has advantages as well as disadvantages. The second and third strategies are most commonly used for the Stillwater Complex. 
Table A1. Terminology used for cumulate igneous rocks of the Stillwater Complex.

[For abbreviations used in "Rock name abbreviation" column: a, augite; b, bronzite; c, chromite; C, cumulate; o, olivine; p, plagioclase]

\begin{tabular}{|c|c|c|c|c|}
\hline Cumulus minerals & $\begin{array}{l}\text { Jones and others (1960); Hess (1960); and } \\
\text { Jackson (1961) }\end{array}$ & Jackson (1967) & $\begin{array}{l}\text { Irvine (1982); Raedeke (1982); } \\
\text { Todd and others (1982) }\end{array}$ & $\begin{array}{c}\text { Rock name } \\
\text { abbreviation }\end{array}$ \\
\hline \multicolumn{5}{|c|}{ Ultramafic cumulates } \\
\hline Bronzite & Bronzitite, feldspathic bronzitite & Bronzite cumulate & Bronzitite, orthopyroxenite & $\mathrm{bC}$ \\
\hline Chromite & Chromitite, feldspathic chromitite & Chromite cumulate & Chromite & $\mathrm{cC}$ \\
\hline Olivine $>$ bronzite & $\begin{array}{l}\text { Granular harzburgite, olivine bronzitite, } \\
\text { feldspathic olivine bronzitite }\end{array}$ & $\begin{array}{l}\text { Olivine-bronzite } \\
\text { cumulate }\end{array}$ & $\begin{array}{l}\text { Granular harzburgite, olivine- } \\
\text { orthopyroxenite }\end{array}$ & $\mathrm{obC}$ \\
\hline Bronzite $>$ olivine & $\begin{array}{l}\text { Olivine bronzitite, feldspathic, olivine } \\
\text { bronzitite }\end{array}$ & $\begin{array}{l}\text { Bronzite-olivine } \\
\text { cumulate }\end{array}$ & -- & boC \\
\hline Olivine $>$ chromite & $\begin{array}{l}\text { Chromite dunite, poikilitic chromite harz- } \\
\text { burgite, feldspathic poikilitic chromite } \\
\text { harzburgite }\end{array}$ & $\begin{array}{l}\text { Olivine-chromite } \\
\text { cumulate }\end{array}$ & Chromite dunite, peridotite & ocC \\
\hline Bronzite, augite & -- & -- & Websterite & -- \\
\hline Bronzite $>$ augite & -- & $\begin{array}{l}\text { Bronzite-augite } \\
\text { cumulate }\end{array}$ & Bronzititic websterite & $\mathrm{baC}$ \\
\hline Augite $>$ bronzite & -- & $\begin{array}{l}\text { Augite-bronzite } \\
\text { cumulate }\end{array}$ & Websterite & $\mathrm{abC}$ \\
\hline \multicolumn{5}{|c|}{ Gabbroid cumulates } \\
\hline Plagioclase & -- & $\begin{array}{l}\text { Plagioclase cumu- } \\
\text { late }\end{array}$ & $\begin{array}{l}\text { Anorthosite, poikilitic anor- } \\
\text { thosite }\end{array}$ & $\mathrm{pC}$ \\
\hline Plagioclase, olivine & -- & -- & Troctolite & poC \\
\hline Plagioclase, augite & -- & $\begin{array}{l}\text { Plagioclase-augite } \\
\text { cumulate }\end{array}$ & Gabbro & $\mathrm{paC}$ \\
\hline $\begin{array}{l}\text { Plagioclase, bronzite, } \\
\text { augite }\end{array}$ & -- & -- & Gabbronorite & $\mathrm{pbaC}$ \\
\hline $\begin{array}{l}\text { Plagioclase }>\text { bronzite } \\
\quad>\text { augite }\end{array}$ & -- & $\begin{array}{l}\text { Plagioclase- } \\
\text { bronzite-augite } \\
\text { cumulate }\end{array}$ & Noritic gabbro & $\mathrm{pbaC}$ \\
\hline $\begin{array}{l}\text { Plagioclase }>\text { augite }> \\
\text { bronzite }\end{array}$ & -- & $\begin{array}{l}\text { Plagioclase-augite- } \\
\text { bronzite cumulate }\end{array}$ & 2-Pyroxene gabbro & pabC \\
\hline $\begin{array}{l}\text { Plagioclase, augite, } \\
\text { olivine }\end{array}$ & -- & -- & Olivine gabbro & paoC \\
\hline $\begin{array}{l}\text { Plagioclase }>\text { augite }> \\
\text { olivine }\end{array}$ & -- & $\begin{array}{l}\text { Plagioclase-augite- } \\
\text { olivine cumulate }\end{array}$ & Olivine gabbro & paoC \\
\hline $\begin{array}{l}\text { Plagioclase, augite, } \\
\text { olivine, bronzite }\end{array}$ & -- & -- & Olivine gabbronorite & paobC \\
\hline $\begin{array}{l}\text { Plagioclase }>\text { augite }> \\
\text { olivine }>\text { bronzite }\end{array}$ & -- & $\begin{array}{l}\text { Plagioclase-augite- } \\
\text { olivine-bronzite } \\
\text { cumulate }\end{array}$ & -- & paobC \\
\hline
\end{tabular}




\section{Rock Names Based on Total Mode}

The earliest descriptions of rock in the Stillwater Complex used names that reflected the total mode of all minerals in the rock (Jackson, 1967). Adjectives were used to describe variations in rock texture. For example, the term harzburgite could refer to an olivine cumulate or an olivine-bronzite cumulate. The adjectives "poikilitic" and "granular" were added to the rock name to distinguish these two rock types. At the time of those studies, an internationally-accepted nomenclature for naming rocks based on total mode had not been adopted. The criteria used to name rocks were not explicitly described in the early studies. The formal terminology proposed by Streckeisen (1973) has not been rigorously applied to rocks from the Stillwater Complex.

\section{Cumulus Nomenclature}

Textures of most Stillwater igneous rocks are characterized by hypidiomorphic-granular fabrics that consist of a "framework" of anhedral to euhedral crystals (cumulus crystals) "cemented" by minerals interstitial to the cumulus grains. Interstitial, postcumulus material may form crystallographically continuous grains that surround and include cumulus crystals (oikocrysts), fill intergranular interstices, or form overgrowths on existing cumulus crystals.

Wager and others (1960) proposed a classification of cumulates based on the character and proportions of the cumulus crystals. Rock names for cumulates are formed by listing the cumulus minerals in decreasing order of abundance followed by the word cumulate. For example, a rock composed principally of cumulus plagioclase, a smaller proportion of cumulus olivine, and postcumulus augite would be called a plagioclase-olivine cumulate. This system for naming rocks has been applied by many geologists in the Stillwater Complex and has been successfully used to map igneous stratigraphy and communicate detailed textural and modal information about rock types.

Cumulate names are cumbersome so most geologists use a system to abbreviate rock names. These abbreviations are formed by using single letters to abbreviate mineral names that are listed in decreasing order of abundance, followed by the letter "c" for cumulate. Five minerals, olivine, low-Ca pyroxene, augite, plagioclase, and chromite, make up most rocks in the complex; abbreviations used for these minerals are "o", "b", "a", "p", and "c", respectively. Using this system, an olivine-bronzite cumulate becomes an "obc". Some geologists have used different type case for mineral abbreviations and the cumulate letter "c". For example, an olivine-bronzite cumulate could be designated either an "obC" or an "OBc". Subscripts indicating the modal proportion (percentage) of minerals can be added to the acronym. $A n$ " $\mathrm{O}_{50} \mathrm{~b}_{30} \mathrm{C}$ " designates an olivinebronzite cumulate that has 50 percent modal olivine and 30 percent modal orthopyroxene (by inference, the remaining 20 percent of the rock is made up of intercumulus minerals). Other geologists indicate modal information by prefacing the acronym with color-index terms such as leucocratic, melanocratic, feldspathic, etc. When the presence of a cumulus mineral is questioned because of low modal abundance or indeterminate textures, some geologists will put the mineral term in parentheses. A " $b(p) C$ " is a bronzite cumulate that may have cumulus plagioclase.

Abbreviations for intercumulus minerals sometimes follow the list of cumulus minerals and the letter " $C$ ". In some cases, if oikocrysts are recognized, the term "oiks" follows the cumulate abbreviation. For example, "pc with pyroxene oiks" is an abbreviation for a plagioclase cumulate with oikocrysts of pyroxene (a mottled anorthosite). Other geologists follow the cumulus letter " $\mathrm{C}$ " with the letter "O" (for oikocrysts) or "I" (for interstitial) and a list of mineral abbreviations. For example, an "oCOb" would be an olivine cumulate with oikocrysts of orthopyroxene.

Cumulate nomenclature works well for most igneous rocks in complex; however, there are important exceptions. Rocks with pegmatoidal textures occur as lenses, pods, or semi-conformable layers. Usually, the mineralogy and modes of the pegmatoidal rocks are similar to enclosing cumulate rocks. If the rock is an olivine cumulate with poikilitic crystals of plagioclase and orthopyroxene, then the pegmatoid will be a feldspathic harzburgite. Geologists using cumulate nomenclature will refer to the rock as an olivine cumulate pegmatoid or an "oCP" where the " $\mathrm{p}$ " at the end of the abbreviation refers to the word pegmatoid. In other rocks, irregular shapes characterize the morphology of cumulus minerals. Geologists have referred to these rocks as ragged. In addition to the irregular crystal shapes, modes and grain size of the rock may vary irregularly over small distances (fractions of an inch to multiple inches). These rocks have been described as vari-textured or heterogeneous-textured. Cumulate nomenclature also is inappropriate to use on the fine-grained, noncumulate rocks found near the base of the complex.

\section{Traditional Rock Names Applied to Modes of Cumulus Minerals}

Irvine (1982) proposed that the most effective approach to naming cumulates is to use both cumulate and traditional names. He suggested that cumulate names serve for classification and analysis, and proposed that familiar names be formulated according to the main cumulus minerals, rather than the total mode of the rock. A comparative listing of traditional names for ultramafic and gabbroic cumulates is provided in table A1. 
Menlo Park Publishing Service Center, California

Manuscript approved for publication September 16, 2014

Edited by Larry Slack and Kate Burgy

Design and layout by Cory Hurd 
